\title{
Endocrine manifestations related to inherited metabolic diseases in adults
}

\author{
Marie-Christine Vantyghem ${ }^{*}$, Dries Dobbelaere ${ }^{2}$, Karine Mention², Jean-Louis Wemeau', Jean-Marie Saudubray ${ }^{3}$ \\ and Claire Douillard ${ }^{1,2}$
}

\begin{abstract}
Most inborn errors of metabolism (IEM) are recessive, genetically transmitted diseases and are classified into 3 main groups according to their mechanisms: cellular intoxication, energy deficiency, and defects of complex molecules. They can be associated with endocrine manifestations, which may be complications from a previously diagnosed IEM of childhood onset. More rarely, endocrinopathies can signal an IEM in adulthood, which should be suspected when an endocrine disorder is associated with multisystemic involvement (neurological, muscular, hepatic features, etc.). IEM can affect all glands, but diabetes mellitus, thyroid dysfunction and hypogonadism are the most frequent disorders. A single IEM can present with multiple endocrine dysfunctions, especially those involving energy deficiency (respiratory chain defects), and metal (hemochromatosis) and storage disorders (cystinosis). Nonautoimmune diabetes mellitus, thyroid dysfunction and/or goiter and sometimes hypoparathyroidism should steer the diagnosis towards a respiratory chain defect. Hypogonadotropic hypogonadism is frequent in haemochromatosis (often associated with diabetes), whereas primary hypogonadism is reported in Alström disease and cystinosis (both associated with diabetes, the latter also with thyroid dysfunction) and galactosemia.

Hypogonadism is also frequent in X-linked adrenoleukodystrophy (with adrenal failure), congenital disorders of glycosylation, and Fabry and glycogen storage diseases (along with thyroid dysfunction in the first 3 and diabetes in the last). This is a new and growing field and is not yet very well recognized in adulthood despite its consequences on growth, bone metabolism and fertility. For this reason, physicians managing adult patients should be aware of these diagnoses.
\end{abstract}

Keywords: Inborn errors of metabolism, endocrine dysfunction, hypogonadism, diabetes mellitus, thyroid dysfunction, hypopituitarism, adrenal failure, hypoparathyroidism

\section{Introduction}

Inborn errors of metabolism (IEM) are rare genetic diseases, which usually have a recessive mode of inheritance. They are classified into 3 main groups according to their mechanisms: cellular intoxication, energy deficiency, and degradation or synthesis defects of complex molecules [1]. This is a new and growing field in adulthood and is not yet very well known.

Endocrine manifestations can be a complication of a previously diagnosed IEM. More rarely they may signal the presence of a new IEM, mostly those involving

\footnotetext{
* Correspondence: mcvantyghem@gmail.com

'Service d'Endocrinologie et Maladies Métaboliques, 1, Rue Polonovski, Hôpital C Huriez., Centre Hospitalier Régional et Universitaire de Lille, 59037 Lille cedex, France

Full list of author information is available at the end of the article
}

glucose metabolism and presenting with hypoglycaemia (see the related article for review). Nevertheless all types of endocrine disorders have been described in IEM (Table 1), and the endocrinologist should be aware of them when an endocrine disorder is associated with multisystem involvement, for example with neurological, muscular and/or hepatic features.

Many endocrine manifestations in IEM might go unrecognized, especially with regard to subclinical dysfunctions. Otherwise, the long-term consequences of IEM on growth, bone metabolism and fertility have not been prospectively investigated.

When fertility is maintained, all pregnancies in patients with a previously diagnosed IEM should be carefully planned and monitored, especially those with dietary management, such as with phenylketonuria.

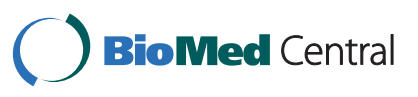


Preconception screening for hormone deficiency, especially hypothyroidism, is recommended in most IEM, as is investigation for gestational diabetes. Genetic counseling should be provided, even though most IEMs, except for mitochondrial diseases, are inherited in an autosomal recessive manner. Prenatal testing for high-risk pregnancies may be discussed if the disease-causing mutations in the family are known.

The aim of this review is to identify the main IEMs in adults that can be revealed or complicated by an endocrine disorder other than hypoglycaemia.

\section{Why endocrine disorders in IEM?}

Hormones play an essential role in the coordination of complex functions such as growth, reproduction, metabolism and energy homeostasis. Hormonal disturbance could contribute to IEM consequences in adulthood. The endocrine system also has paracrine and autocrine functions and is intimately connected with nervous and immune networks by neuromediators and cytokines.

Hormones are classified according to three types: 1) peptide hormones (insulin, parathyroid hormone, pituitary hormones), 2) hormones synthesized from a single amino-acid (catecholamines, thyroid hormones), all derived from tyrosine; and 3) steroid hormones (adrenal and gonadal hormones), all synthesized from cholesterol. Peptide hormones and catecholamines are hydrosoluble and act through different kinds of membrane receptors, the activation of which requires energy. In contrast, steroid and thyroid hormones are liposoluble, circulate bound to specific transporter proteins and are able to cross the cell membrane before acting through cytoplasmic or nuclear receptors. On the whole, the pathophysiology of endocrine dysfunctions in IEM remains poorly understood. IEM can affect all glands, both in their structure and their secretion, but diabetes mellitus, thyroid dysfunction and hypogonadism are the most commonly associated disorders.

The three mechanisms known to interfere with hormone metabolism may act by 1 ) ruining the gland structure through progressive accumulation of toxic substances like metal [iron in haemochromatosis $(>1 /$ 1000, ORPHA139498)], cystine [cystinosis (< 1-9/ 1000000, ORPHA213)] or complex molecules [sphingolipids, glycogen, galactose, abnormal glycosylated compounds, or very long chain fatty acids (VLCFA)]; 2) directly or indirectly disturbing the energy availability required for hormone synthesis (as in respiratory chain disorders) or hormone release (as in underproduction of insulin-causing diabetes in Rogers syndrome (< 1-9/ 1000000, ORPHA49827); or 3) preventing correct hormone biosynthesis in organelles or hormone transport into the target organ, as in cerebral monocarboxylate 8
(MCT8) defect, in which the thyroid hormone cannot cross the blood brain barrier.

\section{Intoxication diseases: Endocrine consequences mainly in haemochromatosis and galactosemia (< 1-9/100000, ORPHA352) (Table 1)}

No obvious endocrine consequences have been described so far in aminoacidopathies, urea cycle disorders or organic acidurias.

In haemochromatosis the pancreas and gonads are the most frequently affected glands with an accumulation of iron. Clinical manifestations can be prevented or improved through treatment. In contrast, hypogonadism in female patients with galactosemia, the mechanism of which is not known, is a unique endocrine complication. It is nearly constant in most cases despite early prospective treatment. Diagnosis is easy and relies on blood and urine analyses.

\section{Disorders of energy metabolism: Frequent multi- endocrine involvement (Table 1)}

Respiratory chain defects and glycogen storage diseases (GSD) are associated with the highest number of endocrine anomalies. Energy deficient production in the former (in which all glands can be involved) and glycogen deposits and secondary glycosylation disturbances in the latter (in which only the pancreas and ovaries are affected) are the most probable (but not demonstrated) mechanisms involved in these disorders.

Diagnosis is difficult and relies on function tests; enzymatic analyses requiring biopsies or cell culture; and molecular analyses.

\section{Organelle disorders involving the synthesis or degradation of complex molecules: Main endocrine consequences on liposoluble hormones (Table 1)}

Fabry disease (<1-9/100000, ORPHA324) and cystinosis (<1-9/1000000, ORPHA213), both lysosomal, X-linked adrenoleukodystrophy (X-ALD) (1-9/100000, ORPHA43), peroxisomal, and congenital disorders of glycosylation (CDG) $(<1 / 1000000$, ORPHA137), both related to endoplasmic reticulum and Golgi dysfunction, are the most frequent IEM responsible for endocrine manifestations in this group (Table 1 ). In cystinosis, lysosomal cystine accumulation may cause diabetes, hypogonadism, hypothyroidism and short stature without a clear mechanism. These complications are only partially prevented or improved with cysteamine treatment. In Fabry disease, subclinical dysthyroidism is frequent and seems to respond to enzyme therapy. Adrenal failure is an almost constant finding in X-ALD and is caused by defective catabolism resulting in VLCFA accumulation, which interferes with steroid hormone 
Table 1 Endocrine manifestations of inborn errors of metabolism in adults

IEM IEM associated with endocrine

General classification

\begin{tabular}{c} 
\\
\hline INTOXICATION \\
Metal intoxication \\
Haemochromatosis \\
Aceruleoplasminemia \\
Wilson's \\
Sugar intolerances \\
Galactosaemia
\end{tabular}

manifestations and most important

$$
\text { mechanism }
$$

$\begin{array}{ccccccc} & \text { Diabetes } & \text { Dysthyroidism } & \begin{array}{c}\text { Hypopara- } \\ \text { thyroidism }\end{array} & \begin{array}{c}\text { Adrenal } \\ \text { failure }\end{array} & \text { Hypogonadism } & \text { Hypopituitarism } \\ \begin{array}{c}\text { Haemochromatosis } \\ \text { Iron storage }\end{array} & \text { Diabetes } & <1 \% & <1 \% & <1 \% & \text { Hypogonadotropic } & <1 \% \text { except for acquired } \\ \text { iron overload and } \\ \text { hypogonadism }\end{array}$

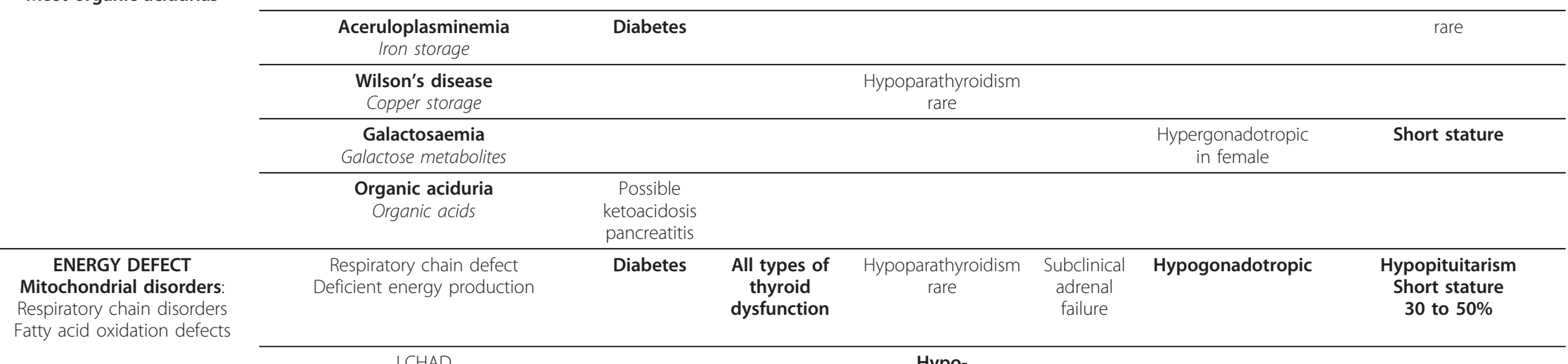

Deficient energy production $\quad \begin{gathered}\text { Hypo- } \\ \text { parathyroidism }\end{gathered}$

\begin{tabular}{|c|c|c|c|c|c|c|}
\hline $\begin{array}{c}\text { Cytoplasmic energy defects } \\
\text { Disorders of glycogen } \\
\text { metabolism }\end{array}$ & $\begin{array}{c}\text { Glycogenosis } \\
\text { Glycogen storage } \\
\text { (type I, III) }\end{array}$ & Diabetes & $\begin{array}{l}\text { Thyroid } \\
\text { dysfunction } \\
\text { (type } \mid \mathrm{lb} \text { ) }\end{array}$ & & $\begin{array}{l}\text { Mixed or } \\
\text { undetemined } \\
\text { PCOS (type I) }\end{array}$ & \\
\hline $\begin{array}{l}\text { COMPLEX MOLECULES } \\
\text { Peroxisomal disorders }\end{array}$ & $\begin{array}{l}\text { X-linked adreno-leukodystrophy } \\
\text { Perrault syndrome } \\
\text { VLCFA accumulation }\end{array}$ & & & $\begin{array}{l}\text { Adrenal } \\
\text { failure }\end{array}$ & $\begin{array}{c}\text { Mixed or } \\
\text { undetemined } \\
\text { (mainly } \\
\text { hypergonadotropic) }\end{array}$ & \\
\hline \multirow[t]{2}{*}{ Lysosomal disorders } & $\begin{array}{c}\text { Fabry disease } \\
\text { Globoside storage in lysosomes }\end{array}$ & & $\begin{array}{c}\text { Subclinical } \\
\text { hypothyroidism }\end{array}$ & $\begin{array}{l}\text { Subclinical } \\
\text { adrenal } \\
\text { failure }\end{array}$ & Infertility & \\
\hline & $\begin{array}{c}\text { Cystinosis } \\
\text { Cystine in lysosomes }\end{array}$ & Diabetes & $\begin{array}{c}\text { Hypothyroidism } \\
75 \%\end{array}$ & & Hypergonadotropic & $\begin{array}{c}\text { Short stature } \\
30 \text { to } 50 \%\end{array}$ \\
\hline $\begin{array}{c}\text { Disorders of intracellular } \\
\text { trafficking and processing such } \\
\text { as } \\
\text { Congenital disorders of } \\
\text { glycosylation } \\
\text { Inborn errors of cholesterol } \\
\text { synthesis. }\end{array}$ & $\begin{array}{c}\text { CDG I } \\
\text { Abnormal glycosylated proteins }\end{array}$ & & $\begin{array}{c}\text { Congenital } \\
\text { hypothyroidism }\end{array}$ & & $\begin{array}{c}\text { Mixed or } \\
\text { undetermined } \\
\text { mainly } \\
\text { hypergonadotropic }\end{array}$ & \\
\hline
\end{tabular}


Table 1 Endocrine manifestations of inborn errors of metabolism in adults (Continued)

\begin{tabular}{|c|c|c|c|c|c|c|}
\hline & $\begin{array}{l}\text { Multisystemic triglyceride storage } \\
\text { disease } \\
\text { Triglyceride storage in endoplasmic } \\
\text { reticulum }\end{array}$ & & $\begin{array}{l}\text { Thyroid } \\
\text { dystrophy }\end{array}$ & & & \\
\hline & $\begin{array}{c}\text { Type } 1 \text { hyperoxaluria } \\
\text { Oxalate }\end{array}$ & & Hypothyroidism & & & $\begin{array}{l}\text { Advanced bone } \\
\text { age }\end{array}$ \\
\hline & $\begin{array}{l}\text { Type B Niemann-Pick disease } \\
\text { Sphingolipid storage in lysosomes }\end{array}$ & & & $\begin{array}{c}\text { Partial } \\
\text { rare }\end{array}$ & & Short stature \\
\hline \multirow[t]{4}{*}{$\begin{array}{l}\text { TRANSPORTER } \\
\text { DEFECT }\end{array}$} & $\begin{array}{c}\text { Rogers syndrome: } \\
\text { Thiamine-sensitive megaloblastic } \\
\text { anaemia } \\
\text { Defective ATP production in B cells }\end{array}$ & Diabetes & & & & \\
\hline & $\begin{array}{c}\text { MCT8 deficiency } \\
\text { Defective T3 transport in neurons }\end{array}$ & & High blood T3 & & & \\
\hline & Alström syndrome & Diabetes & Hypothyroidism & & $\begin{array}{c}\text { Hyper- and } \\
\text { hypogonadotropic } \\
\text { (men) } \\
\text { PCOS in women }\end{array}$ & $\begin{array}{c}\text { Rare hypopituitarism } \\
\text { Initial advanced bone age }\end{array}$ \\
\hline & Selenoprotein deficiency disorder & & Low T3-High T4 & & Oligospermia & Short stature \\
\hline
\end{tabular}

CDG: congenital disorders of glycosylation; IEM: inborn errors of metabolism; LCHAD: long-chain 3-hydroxyacyl-CoA dehydrogenase deficiency; MCT8: Monocarboxylate transporter; PCOS: polycystic ovary syndrome; T3: triiodothyronine; T4: thyroxine; VLCFA: Very long chain fatty acids. 
synthesis. Hypogonadism may also be observed in $\mathrm{X}$ ALD and Perrault syndrome (< 1/1000000, ORPHA2855), in which a defect in peroxisomal VLCFA oxidation has been recently described. Abnormal glycosylation of a variety of proteins involved in hormone metabolism, such as transporters, receptors, and hormone processing could be the cause of hypogonadism and hypothyroidism in CDG syndromes.

This first section has aimed at providing an overview of the main endocrinopathies associated with a given IEM, summarized in Table 1 . The next sections will aim to clarify which IEMs can be associated with a given endocrinological disturbance, such as diabetes (Table 2), dysthyroidism (Table 3) and hypogonadism (Table 4).

\section{Diabetes}

Several IEM can be associated with diabetes mellitus (Table 2). The main mechanisms of diabetes in IEM involve either defects of insulin secretion or insulin resistance, which might be promoted by liver or muscle involvement and estrogen deficiency [1]. The insulinopenic forms of diabetes are not associated with autoimmune features, and ketoacidosis might be the presenting sign, especially in haemochromatosis and mitochondrial diseases. In addition, the phenotype of some disorders might vary from hypo- to hyperglycemia according to age or genotype [defects in biotinidase (1-9/100000, ORPHA79241), organic acidurias, $A B C C 8$ mutations].

\section{Diabetes likely to signal an IEM: Trend towards insulinopenia (Table 2)}

Hereditary haemochromatosis is the most frequent IEM in adults [2]. The phenotype varies according to the penetrance of the mutations of the HFE 1 gene, which affects $0.3 \%$ of the general population. The prevalence of diabetes in haemochromatosis, usually $20 \%$ to $50 \%$, has decreased to $5 \%$ to $10 \%$ due to earlier genetic screening. In contrast, the prevalence of haemochromatosis in the diabetic population is $1.3 \%$. Increased duodenal iron absorption due to an impairment of hepcidin synthesis accounts for the development of cellular iron excess in most cases of haemochromatosis. Genes other than HFE1 may account for hereditary forms of haemochromatosis. The form caused by mutations of the hemojuvelin gene has a juvenile onset and is often revealed by cardiopathy and hypogonadism. Non-transferrin-bound iron plays an important role in cellular iron damage through an increase in oxidative stress. First, liver iron overload promotes the occurrence of insulin-resistant diabetes [3]. The pancreas $§$ cells may then be progressively destroyed, leading to $C$-peptide negative diabetes and requiring insulin therapy besides iron depletion.
Aceruloplasminemia (< 1-9/1000000, ORPHA48818) is characterized by the accumulation of iron in the liver, islets of Langerhans and the brain, related to decreased cellular iron egress, in contrast with most other types of iron overload [4]. The treatment with phlebotomies and iron chelation is efficient in preventing both neurological involvement and diabetes [5]. Annual glucose tolerance testing, starting at age 15 years, has been recommended.

Mitochondrial diabetes makes up 0.06 to $2.8 \%$ of cases of type 2 diabetes and should be suspected in young, lean patients with non-autoimmune diabetes and neurosensory or muscular involvement [6-9]. It is maternally inherited and may be associated with multiple endocrine dysfunctions. Diabetes can progressively evolve towards insulin requirement, but inaugural ketoacidosis has also been reported. The need for insulin treatment is common, but the diabetes is usually easy to control. Proteinuria and renal insufficiency occur more frequently than usual in diabetes [10]. This form of diabetes is explained by insulinopenia, which is either related to the destruction of $\beta$ cells or to a defect of insulin secretion as a consequence of the energy defect. In the first case, the production of ATP through the glycolysis pathway, too low to ensure normal cell function, leads to cell death, as confirmed histologically by a reduction in the number of $\beta$ cells $[11,12]$. It also prevents closure of the potassium channels, inducing a defect in insulin secretion [13-15]. Insulin sensitivity in skeletal muscle is also decreased [15].

The most frequent genetic abnormality is the single mutation A3243G (mitochondrial DNA), particularly in MIDD (< 1-9/1000000, ORPHA225) and MELAS (< 1-5/ 10000 , ORPHA550) syndromes. Heteroplasmy plays a central role in the phenotypic expression of the same mutation, and a higher level has been found in mitochondrial diabetes in the endocrine pancreatic $\beta$ cells than in the exocrine cells and blood leukocytes [16]. Correction of the consequences of mitochondrial 3243A > G mutation by tRNA import into mitochondria has been attempted, raising new hopes in the treatment of the disease [17].

Complex rearrangements are more often encountered in Kearns-Sayre syndrome (<1-9/100000, ORPHA480), isolated diabetes and Wolfram syndrome (< 1-9/ 1000000, ORPHA3463) [18]. Wolfram syndrome, also called DIDMOAD (Diabetes Insipidus, Diabetes Mellitus, Optic Atrophy, Deafness) may also be linked to an autosomal recessive mutation of the WFS1 gene encoding Wolframin (nuclear DNA) [19]. In this case, diabetes appears earlier in males than in females, with low plasma insulin concentration and increased proinsulin/ insulin ratio, which in the long-term may lead to insulin deficiency [20]. 
Table 2 Main causes of diabetes mellitus related to inborn errors of metabolism (IEM)

\begin{tabular}{|c|c|c|c|c|}
\hline DISEASES & GENERAL CONTEXT & $\begin{array}{c}\text { ENDOCRINE DYSFUNCTION: } \\
\text { DIABETES }\end{array}$ & IEM DIAGNOSIS & TREATMENT \\
\hline \multicolumn{5}{|l|}{$\begin{array}{l}\text { Diabetes likely to } \\
\text { signal an IEM: rather } \\
\text { insulinopaenic } \\
\end{array}$} \\
\hline $\begin{array}{c}\text { Hereditary } \\
\text { haemochromatosis }\end{array}$ & $\begin{array}{c}\text { Melanodermy } \\
\text { Hepatomegaly } \\
\text { Rheumatologic involvement } \\
\text { Early heart involvement in juvenile } \\
\text { forms } \\
\text { Complication: cirrhosis and } \\
\text { hepatocarcinoma }\end{array}$ & $\begin{array}{l}\text { All types of Diabetes } 10 \% \\
\text { - First insulin resistance } \\
\text { - Then insulinopenia } \\
\text { Possible inaugural ketoacidosis } \\
\text { Hypogonadotropic } \\
\text { hypogonadism }\end{array}$ & $\begin{array}{c}\text { Transferrin saturation > 45\%, } \\
\text { serum ferritin > } 200 \text { (F), } 300 \text { (M) } \\
\mu \mathrm{H} / \mathrm{l} \\
\text { HFE gene mutation: HFE-1: } 97 \% \\
\text { in Caucasians } \\
\text { HFE-2: hemojuveline and } \\
\text { hepcidin } \\
\text { HFE-3: transferrin receptor } \\
\text { HFE-4: ferroportin (autosomal } \\
\text { dominant) } \\
\text { Others }\end{array}$ & $\begin{array}{c}\text { Insulin-sensitiser } \\
\text { Insulin therapy } \\
\text { Phlebotomy }\end{array}$ \\
\hline $\begin{array}{c}\text { Hereditary } \\
\text { acoeruloplasminemia }\end{array}$ & $\begin{array}{c}\text { Adult-onset neurological and } \\
\text { psychiatric disease (chorea, } \\
\text { cerebellar ataxia, retinal } \\
\text { degeneration) } \\
\text { Differential diagnosis of high blood } \\
\text { ferritin } \\
\text { - Normal transferrin saturation } \\
\text { Dysmetabolic hepatosiderosis } \\
\text { Inherited atransferrinaemia, } \\
\text { Gaucher's disease } \\
\text {-Increased transferrin saturation } \\
\text { Multiple blood transfusions } \\
\text { (thalassaemia) }\end{array}$ & $\begin{array}{l}\text { Diabetes mellitus due to iron } \\
\text { overload, }\end{array}$ & $\begin{array}{c}\text { Anaemia } \\
\text { High serum ferritin } \\
\text { Absence of serum } \\
\text { coeruloplasmin } \\
\text { Coeruloplasmin gene mutations }\end{array}$ & $\begin{array}{l}\text { Insulin therapy } \\
\text { Iron chelation }\end{array}$ \\
\hline $\begin{array}{c}\text { Mitochondrial } \\
\text { diseases } \\
\text { (respiratory chain } \\
\text { defects) } \\
\text { MIDD } \\
\text { MELAS } \\
\text { Kearns-Sayre } \\
\text { syndrome } \\
\text { DIDMOAD }\end{array}$ & $\begin{array}{l}\text { Deafness, pigmentary retinitis, } \\
\text { Neuromuscular symptoms } \\
\text { Kidney insufficiency } \\
\text { Maternal inheritance }\end{array}$ & $\begin{array}{c}\text { Non-autoimmune diabetes in a } \\
\text { lean patient }>30 \text { years, possible } \\
\text { inaugural ketoacidosis } \\
\text { Thyroid dysfunction } \\
\text { More rarely hypoparathyroidism, } \\
\text { adrenal insufficiency, } \\
\text { hypogonadism, hypopituitarism } \\
\text { Possible diabetes insipidus }\end{array}$ & $\begin{array}{c}\text { Blood lactates/pyruvate ratio } \\
\text { Blood BOHbutyrate/acetoacetate } \\
\text { ratio } \\
\text { CSF lactates- urinary organic } \\
\text { acids } \\
\text { Plasma amino acids: high } \\
\text { alanine and proline } \\
\text { Muscle biopsy } \\
\text { Mitochondrial DNA study } \\
\text { Mitochondrial DNA or WFS1 } \\
\text { gene study }\end{array}$ & $\begin{array}{l}\text { Insulin therapy } \\
\text { Coenzyme Q10 }\end{array}$ \\
\hline $\begin{array}{l}\text { Channelopathies } \\
\text { (ABCC8 gene) }\end{array}$ & $\begin{array}{c}\text { Sometimes childhood fasting } \\
\text { hypoglycaemia }\end{array}$ & $\begin{array}{l}\text { Early adult-onset non- } \\
\text { autoimmune diabetes }\end{array}$ & $\begin{array}{l}\text { Heterozygous mutation in } \\
A B C C 8 \text { gene (autosomal } \\
\text { dominant) }\end{array}$ & $\begin{array}{l}\text { Sulfonylurea/ } \\
\text { insulin }\end{array}$ \\
\hline \multicolumn{5}{|l|}{$\begin{array}{c}\text { Diabetes } \\
\text { complicating a } \\
\text { previously diagnosed } \\
\text { IEM } \\
\end{array}$} \\
\hline $\begin{array}{l}\text { Glycogen storage } \\
\text { disease } \\
\text { I and III }\end{array}$ & $\begin{array}{l}\text { Hepatomegaly (I and III) } \\
\text { Mild muscular symptoms (Type III) } \\
\text { Childhood fasting hypoglycaemia }\end{array}$ & $\begin{array}{l}\text { Progression to adult fasting } \\
\text { hypoglycaemia with } \\
\text { postprandial hyperglycaemia }\end{array}$ & $\begin{array}{l}\text { Fasting hypoglycaemia } \\
\text { Lactic acidosis (preprandial I, } \\
\text { postprandial III) } \\
\text { Glc-6-P (I) and debranching } \\
\text { enzyme (III) genes mutation }\end{array}$ & $\begin{array}{c}\text { Alpha- } \\
\text { glucosidase } \\
\text { inhibitor and/or } \\
\text { Insulin-sensitiser }\end{array}$ \\
\hline Alström syndrome & $\begin{array}{c}\text { Short stature } \\
\text { Renal failure } \\
\text { Dilated myocardiopathy } \\
\text { Blindness, deafness }\end{array}$ & $\begin{array}{c}\text { Early insulin-resistant diabetes } \\
\text { mellitus (82\%) } \\
\text { Childhood obesity } \\
\text { Hypogonadism } \\
\text { Hypothyroidism }\end{array}$ & $\begin{array}{c}\text { Major Hypertriglyceridaemia } \\
\text { HypoHDLemia } \\
\text { ALMS / gene mutation }\end{array}$ & $\begin{array}{l}\text { Insulin-sensitiser } \\
\text { Insulin therapy }\end{array}$ \\
\hline Cystinosis & $\begin{array}{l}\text { early-onset Fanconi syndrome with } \\
\text { polyuria and hypophosphatemic } \\
\text { rickets } \\
\text { then complicated by blindness } \\
\text { myopathy, central nervous system } \\
\text { impairment- renal insufficiency. }\end{array}$ & $\begin{array}{c}\text { Diabetes mellitus } \mathbf{2 5 \%} \\
\text { Hypothyroidism 75\% } \\
\text { Hypogonadism } 74 \% \text { (males) } \\
\text { Delayed puberty } \\
\text { Growth retardation }\end{array}$ & $\begin{array}{l}\text { Renal tubular Fanconi syndrome } \\
\text { (hypokalemia, acidosis, } \\
\text { dehydration, kidney loss of } \\
\text { phosphate, glucose and amino } \\
\text { acids)High leukocyte cystine } \\
\text { Cystinosin (CTNS) gene mutatin }\end{array}$ & $\begin{array}{c}\text { Electrolyte/ } \\
\text { vitamin } \\
\text { supplementation } \\
\text { Indomethacin } \\
\text { Cysteamine }\end{array}$ \\
\hline
\end{tabular}


Table 2 Main causes of diabetes mellitus related to inborn errors of metabolism (IEM) (Continued)

\begin{tabular}{ccccc}
\hline $\begin{array}{c}\text { Thiamine-responsive } \\
\text { megaloblastic } \\
\text { anaemia syndrome }\end{array}$ & $\begin{array}{c}\text { Megaloblastic anaemia } \\
\text { Progressive perception deafness in } \\
\text { infancy }\end{array}$ & $\begin{array}{c}\text { Thiamine-sensitive diabetes } \\
\text { mellitus, frequently insulin- } \\
\text { dependent; possible ketoacidosis }\end{array}$ & $\begin{array}{c}\text { SLC19A2 gene inactivation } \\
\text { (thiamine transporter THTR1 } \\
\text { gene) }\end{array}$ & $\begin{array}{c}\text { B1Vitamin } \\
\text { Insulin therapy }\end{array}$ \\
\hline Organic aciduria & Cognitive disorders & $\begin{array}{c}\text { Transient hyperglycaemic } \\
\text { ketoacidosis }\end{array}$ & Urinary organic acids & Insulin therapy \\
\hline
\end{tabular}

The other genetic types of diabetes have been ruled out: Down's, Klinefelter, Turner, Friedreich, Huntington, Laurence-Moon-Biedl, Prader-Willi, porphyria, ToniDebre-Fanconi, cystic fibrosis, Maturity Onset Diabetes of the Young (MODY) and neonatal diabetes. Definitions: F: female; M: male; MIDD: Maternal Inherited Diabetes Deafness; MELAS: Myopathy, Encephalopathy, Lactic Acidosis, Stroke; DIDMOAD: Diabetes Insipidus, Diabetes Mellitus, Optic Atrophy, and Deafness or Wolfram syndrome; Kearns-Sayre syndrome: Starting before 20 years with progressive ophthalmoplegia, retinitis pigmentosa, cardiac conduction disorders and multisystemic injury. Thiamine-responsive megaloblastic anaemia syndrome or Rogers syndrome. CSF: cerebrospinal fluid. G-6-P: Glucose-6-phosphatase.

\section{Monogenic form of diabetes by ABCC8 gene muta-} tions: Activating heterozygous mutations in KCNJ11 and $A B C C 8$ genes, which form the ATP-sensitive $\mathrm{K}+$ channel, usually causes transient or permanent neonatal diabetes. Nevertheless, the occurrence of diabetes in young adults has recently been reported and is related to a heterozygous activating mutation of the $A B C C 8$ gene encoding the sulphonylurea receptor 1 (SUR1) [21]. The clinical phenotype of these patients is heterogeneous, either sensitive to sulfonylurea or requiring insulin. It appears to be modified by variable sensitivity to insulin according to hyperinsulinemic euglycemic clamp studies [22]. The phenotype associated with dominant inactivating (loss-of-function) $A B C C 8 / K C N J 11$ mutations, known to range from asymptomatic macrosomia to persistent hyperinsulinemic hypoglycemia in childhood, may also be an important cause of inherited early-onset diabetes mellitus in adults [23].

In conclusion, diabetes that is likely to reveal an IEM in adults is mainly related to hereditary haemochromatosis in association with hypogonadism, or to mitochondrial diabetes in association with multiple endocrinopathies. $A B C C 8 / K C N J 11$ mutations have been more recently identified in early-onset non-type 1 diabetes. The prognosis of hereditary haemochromatosis has improved due to earlier genetic screening.

\section{Diabetes complicating a previously diagnosed IEM (Table 2)}

Glycogen storage disease (GSD or glycogenosis) is the result of defects in the processing of glycogen synthesis or breakdown within muscles, liver, and other cell types. GSD is classified according to the type of genetically defective enzymes and induces hepatomegaly, hypoglycemia and/or muscular symptoms. GSD, especially types I (ORPHA364) and III (ORPHA366), can be complicated by diabetes in the later stage [24]. Type I GSD is initially associated with severe fasting hypoglycaemia. Postprandial hyperglycemia (sometimes in contrast with fasting hypoglycaemia) can occur in adulthood [25]. This fact could be explained either by recurrent pancreatitis episodes linked to hypertriglyceridemia, thus leading to insulin secretion impairment, or to an adaptive mechanism of the glucose receptor, GLUT2, for reducing the secretion of insulin. Diabetes is also promoted by insulin resistance related to liver and/or muscle dysfunction [26,27]. Gene therapy is under evaluation.

Alström syndrome: Alström syndrome (< 1-9/ 1000000, ORPHA64) is characterized by a wide-ranging spectrum of phenotypes. In a series of 182 patients, hyperinsulinemia developed in early childhood (92\%) and progressed to type 2 diabetes mellitus in $82 \%$ of those older than 16 years. Hypertriglyceridemia (54\%) precipitated pancreatitis in 8 patients [28]. An oral glucose tolerance test should be considered annually, since fasting blood glucose is often normal at diagnosis. If blood glucose control is poor on insulin therapy, escalating doses may not be effective [29]. Unlike insulinresistance indices, $\beta$-cell function indices show a significant reduction with age [30]. Mutations of the ALMS1 gene cause dysfunction of the primary cilium, an organelle involved in cell sensing, as in another model of genetic obesity, the Bardet-Biedl syndrome. The higher frequency of diabetes in Alström syndrome is explained by the specific role of $A L M S 1$ in $\beta$-cell function and/or peripheral insulin signaling pathways, in parallel with adipogenesis impairment [31].

Cystinosis is a lysosomal disease, which induces an intracellular accumulation of cystine due to transportation impairment. It presents as a multisystemic injury dominated by renal manifestations. Twenty-four percent of a cohort of 100 patients had diabetes, with a quarter of those needing insulin therapy, in addition to other endocrinopathies such as hypothyroidism and hypogonadism [32-34]. The pathophysiology of diabetes mellitus is mainly due to decreased insulin secretion associated with pancreatic fibrosis. Microarray studies have shown that some of the differentially regulated genes in cystinosis were involved in mitochondrial dysfunction, endoplasmic reticulum and oxidative stress, as well as immune function [35].

Thiamine-sensitive megaloblastic anemia (Rogers syndrome) [36] is characterized by diabetes and deafness due to a lack of thiamine in pancreatic islet and cochlear cells. It is caused by a defect in the active 
Table 3 Main inborn errors of metabolism associated with thyroid dysfunction

\begin{tabular}{|c|c|c|c|c|}
\hline DISEASES & $\begin{array}{c}\text { CLINICAL } \\
\text { MANIFESTATIONS }\end{array}$ & ENDOCRINE DYSFUNCTION: DYSTHYRODISM & DIAGNOSIS & TREATMENT \\
\hline \multicolumn{5}{|l|}{ Energy defect } \\
\hline $\begin{array}{l}\text { Mitochondrial } \\
\text { disease }\end{array}$ & $\begin{array}{l}\text { Involving seemingly } \\
\text { unrelated organs } \\
\text { Maternal inheritance } \\
\text { Deafness, retinitis } \\
\text { pigmentosa } \\
\text { Short stature, } \\
\text { Neuromuscular } \\
\text { symptoms } \\
\text { Kidney insufficiency }\end{array}$ & $\begin{array}{c}\text { Goiter, hypo-/hyperthyroidism, thyrotropic } \\
\text { insufficiency } \\
\text { Non-autoimmune diabetes in a lean patient > } 30 \\
\text { years } \\
\text { More rarely hypoparathyroidism, adrenal } \\
\text { insufficiency, hypogonadism, hypopituitarism }\end{array}$ & $\begin{array}{c}\text { Blood lactate/pyruvate } \\
\text { ratio (high) } \\
\text { Blood BOH butyrate/ } \\
\text { acetoacetate ratio: high } \\
\text { CSF lactate (high) } \\
\text { Urinary organic acids } \\
\text { Plasma amino acids: } \\
\text { high alanine \& proline } \\
\text { Muscle biopsy } \\
\text { Mitochondrial DNA } \\
\text { study }\end{array}$ & Discuss coenzyme Q10 \\
\hline Glycogenosis & $\begin{array}{l}\text { Liver involvement } \\
\text { Infections in type Ib } \\
\text { Growth failure } \\
\text { Renal complications } \\
\text { in adulthood }\end{array}$ & $\begin{array}{c}\text { Increased prevalence of autoimmune } \\
\text { hypothyroidism in type I b } \\
\text { Children: fasting ketotic hypoglycaemia } \\
\text { Adults: } \\
\text { I, III types: polycystic ovary syndrome, diabetes, } \\
\text { osteoporosis } \\
\text { VI, IX types: spontaneous recovering delayed } \\
\text { puberty }\end{array}$ & $\begin{array}{c}\text { Fasting hypoglycaemia } \\
\text { Hyper-lipaemia, } \\
\text {-uricaemia } \\
\text { Hyperlactataemia: } \\
\text { - fasting predominant: } \\
\text { type I } \\
\text { - postprandial } \\
\text { predominant: type III, VI, } \\
\text { IX } \\
\text { Leukocytes DNA gene } \\
\text { mutation }\end{array}$ & $\begin{array}{c}\text { Frequent food intake } \\
\text { Uncooked cornstarch } \\
\text { Low carbohydrate } \\
\text { glycaemic index } \\
\text { Night enteral feeding } \\
\text { G-CSF in Ib type, } \\
\text { Allopurinol } \\
\text { Avoid oestroprogestative } \\
\text { pills }\end{array}$ \\
\hline \multicolumn{5}{|l|}{$\begin{array}{l}\text { Degradation and } \\
\text { synthesis of } \\
\text { complex molecules }\end{array}$} \\
\hline Fabry disease & $\begin{array}{l}\text { Acroparesthesia } \\
\text { Angiokeratoma } \\
\text { Stroke at young age } \\
\text { Renal, heart and eye } \\
\text { involvement in boys }\end{array}$ & $\begin{array}{c}\text { Subclinical hypothyroidism } \\
\text { Isolated case report of subclinical adrenal } \\
\text { insufficiency and hypoparathyroidism } \\
\text { Infertility, osteoporosis }\end{array}$ & $\begin{array}{l}\text { Alpha-galactosidase A } \\
\text { in males } \\
\text { Leukocytes GLA gene } \\
\text { mutation in females } \\
\quad \text { (X-linked) }\end{array}$ & $\begin{array}{l}\text { Substitutive recombinant } \\
\text { enzyme therapy }\end{array}$ \\
\hline Cystinosis & $\begin{array}{l}3 \text { forms: infantile, } \\
\text { juvenile, ophthalmic } \\
\text { (adulthood) } \\
\text { Liver and muscle } \\
\text { involvement } \\
\text { Evolution to end } \\
\text { stage renal disease }\end{array}$ & $\begin{array}{c}\text { Hypothyroidism }>\mathbf{5 0 \%} \\
\text { Hypergonadotropic hypogonadism (in males) } \\
\text { Insulin-dependant diabetes } \\
\text { Growth failure }\end{array}$ & $\begin{array}{l}\text { Gluco-phospho-aminic } \\
\text { diabetes } \\
\text { Hypokalaemia, acidosis, } \\
\text { Leukocyte cystin } \\
\text { measurement } \\
\text { Leukocytes CTNS gene } \\
\text { mutation }\end{array}$ & $\begin{array}{l}\text { Electrolyte } \\
\text { supplementation } \\
\text { Vitamins } \\
\text { Indomethacin } \\
\text { Cysteamine }\end{array}$ \\
\hline $\begin{array}{c}\text { Type } 1 \\
\text { hyperoxaluria }\end{array}$ & $\begin{array}{l}\text { Recurrent oxalic } \\
\text { lithiasis leading to } \\
\text { end stage renal } \\
\text { disease } \\
\text { Bone, eye, heart } \\
\text { involvement }\end{array}$ & $\begin{array}{c}\text { Hypothyroidism } \\
\text { - often severe } \\
\text { - sometimes signalling disease }\end{array}$ & $\begin{array}{c}\text { Hyperoxaluria } \\
\text { Hyperglycoluria } \\
\text { Alanine-glyoxylate- } \\
\text { aminotransferase } \\
\text { measurement on liver } \\
\text { biopsy } \\
\text { Leukocytes AGXT gene } \\
\text { mutation }\end{array}$ & $\begin{array}{l}\text { Abundant hydration } \\
\text { Urine alkalinisation } \\
\text { Pyridoxine phosphate } \\
\text { Kidney and liver } \\
\text { transplantation }\end{array}$ \\
\hline $\begin{array}{l}\text { Neutral lipid } \\
\text { storage disease }\end{array}$ & $\begin{array}{l}\text { Ichtiosis or Chanarin- } \\
\text { Dorfman syndrome } \\
\text { or myopathy/ } \\
\text { cardiomyopathy } \\
\text { Hepatomegaly } \\
\text { Central nervous } \\
\text { system involvement }\end{array}$ & $\begin{array}{l}\text { Nodular dystrophy of the thyroid } \\
\text { (clear cells follicular adenoma) }\end{array}$ & $\begin{array}{c}\text { Normal lipid levels } \\
\text { CPK sometimes } \\
\text { moderately increased } \\
\text { Accumulation of } \\
\text { triglycerides } \\
\text { - in leukocytes (Jordan's } \\
\text { abnormality) } \\
\text { - in muscle, skin } \\
\text { fibroblasts, liver } \\
\text { (steatosis) } \\
\text { Leukocytes or } \\
\text { fibroblasts ABHD5 or } \\
\text { PNPLA2 gene mutation }\end{array}$ & No effective treatment \\
\hline
\end{tabular}


Table 3 Main inborn errors of metabolism associated with thyroid dysfunction (Continued)

\begin{tabular}{|c|c|c|c|c|}
\hline $\begin{array}{l}\text { MCT8 deficiency } \\
\text { Or Allan-Erndon- } \\
\text { Dudley syndrome }\end{array}$ & $\begin{array}{l}\text { Severe cognitive } \\
\text { deficiency, } \\
\text { Hypotonia and } \\
\text { dystonic movement } \\
\text { Progressive spastic } \\
\text { quadriplegia in boys }\end{array}$ & $\begin{array}{l}\text { High serum } \mathrm{T}_{3} \text { - low serum } \mathrm{rT}_{3} \\
\text { Low serum } \mathrm{T}_{4} \text { (sometimes normal) } \\
\text { Normal serum TSH (or slightly elevated) } \\
\text { Nodular dystrophy of the thyroid }\end{array}$ & $\begin{array}{l}\text { Leukocytes MCT8 gene } \\
\text { mutation } \\
\text { (X-linked) }\end{array}$ & $\begin{array}{c}\text { Propylthiouracil and L- } \\
\text { thyroxin }\end{array}$ \\
\hline $\begin{array}{l}\text { Congenital } \\
\text { disorders of } \\
\text { glycosylation }\end{array}$ & $\begin{array}{l}\text { Affect nearly all } \\
\text { organs and systems } \\
\text { Often, significant } \\
\text { neurological } \\
\text { component. }\end{array}$ & $\begin{array}{c}\text { Most of the time difficulties in TSH } \\
\text { measurement } \\
\text { Always check with a reference method } \\
\text { Rare congenital hypothyroidism } \\
\text { Hypogonadism }\end{array}$ & $\begin{array}{l}\text { N-glycosylation diseases: } \\
\text { serum transferrin } \\
\text { isoelectrofocusing } \\
\text { O-glycosylation disorders: } \\
\text { apo Clll isoelectro- } \\
\text { focusing, } \\
\text { leukocytes DNA } \\
\text { molecular study }\end{array}$ & $\begin{array}{l}\text { Inhibitors of } \\
\text { phosphomannose } \\
\text { isomerase under } \\
\text { evaluation in CDG-la } \\
\text { Mannose in CDG-lb }\end{array}$ \\
\hline $\begin{array}{c}\text { Selenoprotein } \\
\text { deficiency disorder }\end{array}$ & $\begin{array}{l}\text { Myopathy, } \\
\text { Dermal } \\
\text { photosensitivity }\end{array}$ & $\begin{array}{c}\text { Deficiency of deiodinases: low serum T3 and and } \\
\text { high serum T4 } \\
\text { Oligospermia }\end{array}$ & $\begin{array}{l}\text { Leukocytes SECISBP2 } \\
\text { gene mutation }\end{array}$ & \\
\hline \multicolumn{5}{|l|}{$\begin{array}{c}\text { Intoxication } \\
\text { disorders }\end{array}$} \\
\hline Haemochromatosis & $\begin{array}{l}\text { Liver, rheumatologic } \\
\text { and heart } \\
\text { involvement }\end{array}$ & $\begin{array}{c}\text { Hypo- and hyperthyroidism: } \leq \mathbf{1 \%} \\
\text { Diabetes (10\%)Peripheral hypogonadism (5-10\%) } \\
\text { Adrenal insufficiency, hypopituitarism, and } \\
\text { hypoparathyroidism: similar to the general } \\
\text { population (except for secondary iron overload) }\end{array}$ & $\begin{array}{l}\text { Transferrin saturation } \\
\text { Serum ferritin } \\
\text { Leukocytes HFE gene } \\
\text { mutation }\end{array}$ & $\begin{array}{l}\text { Phlebotomy } \\
\text { Iron chelation }\end{array}$ \\
\hline
\end{tabular}

Abbreviations 3,3',5-triiodothyronine: $\mathrm{T}_{3} ; 3,3^{\prime}, 5^{\prime}$-triiodothyronine: reverse $\mathrm{T}_{3}$ or $\mathrm{rT}_{3}$; tetraiodothyronine: thyroxine or $\mathrm{T}_{4}$; $\mathrm{ATGL}$ or Adipose triglyceride lipase, encoded by the gene PNPLA2 or patatin-like phospholipase domain containing 2; or alpha/beta-hydrolase domain-containing protein 5, encoded by $A B H D 5$ gene (also called comparative gene identification-58); AGTX or Alanine-glyoxylate-aminotransferase gene; CDG or congenital disorders of glycosylation; CPK: creatin phospho kinase; CSF: cerebrospinal fluid; MCT8 (Monocarboxylate Transporter 8) deficiency or Allan-Erndon-Dudley syndrome or SLC16A2-Specific Thyroid Hormone Cell Transporter Deficiency; SECISBP2 or Sec insertion sequence-binding protein 2 (also known as SBP2)

transport of thiamine (thiamine transporter 1 or THTR1), which leads to $ß$ cell apoptosis and insulin secretion impairment. In contrast with neurosensory disorders, anemia and diabetes improve with pharmacological doses of oral thiamine and may lead to insulin discontinuation. Poor blood glucose control however reoccurs most of the time during adolescence, thus requiring resumption of insulin therapy $[37,38]$.

Organic Aciduria: Propionic (< 1-9/100000, ORPHA35), methylmalonic (< 1/1000000, ORPHA26) and isovaleric acidemias (1-9/100000, ORPHA33) are sometimes discovered during infancy through the presence of hyperglycemic ketoacidosis, which may suggest diabetes, particularly during pancreatitis, one of the complications of the disease $[39,40]$. Diabetes has never been reported to be a presenting manifestation of organic aciduria in adulthood, but should be kept in mind since mitochondrial dysfunction has been reported to be associated with it [41].

Finally, diabetes may also complicate a previously diagnosed IEM, particularly those inducing impairment of the degradation or synthesis of complex molecules. In this group, hypothyroidism or hypogonadism are frequently associated endocrine disorders.

In conclusion, diabetes, mainly linked to $ß$ cell dysfunction, is encountered in the 3 types of IEM: intoxication disorders (mainly haemochromatosis, sometimes organic aciduria), disorders of energy metabolism (respiratory chain defects, GSD) or organelle disorders (Alström and Rogers syndromes, cystinosis). Of these IEM, iron overload has a special place in adulthood since hereditary haemochromatosis linked to a mutation of the HFE 1 gene is one of the most frequent metabolic diseases, even if its penetrance is variable and is modulated by environmental factors such as body weight and alcohol.

\section{Dysthyroidism}

The IEMs associated with dysthyroidism in adulthood mainly involve energy metabolism defects and the degradation or synthesis of complex molecules (Table 3). Primary hypothyroidism is the most frequent feature, although pituitary participation cannot be excluded in most cases. Goiter has also been reported. Hyperthyroidism is more questionable. Besides the consequences of dysthyroidism, hypothyroidism can affect reproduction and glucose metabolism. When a pregnancy is possible, preconceptional FT4 and TSH should be assessed, taking into account the known influence of even subclinical hypothyroidism on early fetal brain development and long-term cognitive function [42]. Otherwise, overt hypothyroidism has been associated with increased rates of spontaneous abortion, premature delivery and/or low birth weight, fetal distress in labor, and perhaps gestational hypertension, emphasizing the importance of thyroid balance before and during pregnancy [43]. 
Table 4 Main IEM associated with hypogonadism

\begin{tabular}{|c|c|c|c|c|}
\hline DISEASES & $\begin{array}{c}\text { CLINICAL } \\
\text { MANIFESTATIONS }\end{array}$ & ENDOCRINE DYSFUNCTION: HYPOGONADISM & DIAGNOSIS & TREATMENT \\
\hline \multicolumn{5}{|l|}{ Intoxication diseases } \\
\hline Haemochromatosis & $\begin{array}{l}\text { Melanodermy } \\
\text { Hepatomegaly } \\
\text { Rheumatologic signs } \\
\text { Early heart } \\
\text { involvement in } \\
\text { juvenile forms } \\
\text { Cirrhosis and } \\
\text { hepatocarcinoma }\end{array}$ & $\begin{array}{c}\text { Hypogonadotrophic hypogonadism } \\
\text { - 5\%-10\% (HFE1)- early-onset in HFE-2 with hear } \\
\text { involvementDiabetes 10\% } \\
\text { Hypo- and hyperthyroidism: } \leq 1 \% \\
\text { Adrenal insufficiency, hypopituitarism, and } \\
\text { hypoparathyroidism: similar to the general } \\
\text { population (except for secondary iron overload) }\end{array}$ & $\begin{array}{l}\text { Transferrin saturation } \\
\text { Serum ferritin } \\
\text { Leukocytes HFE gene } \\
\text { mutation }\end{array}$ & $\begin{array}{l}\text { Phlebotomy } \\
\text { Iron chelation } \\
\text { Androgen with caution } \\
\text { due to a possible } \\
\text { increased risk of } \\
\text { hepatocarcinoma }\end{array}$ \\
\hline Galactosaemia & $\begin{array}{c}\text { Mental retardation } \\
\text { Cataracts } \\
\text { Osteoporosis }\end{array}$ & Hypergonadotropic hypogonadism: $75-96 \%$ & $\begin{array}{l}\text { Blood and urine } \\
\text { measurement of } \\
\text { galactose and } \\
\text { galactitol } \\
\text { Leukocytes GALT } \\
\text { gene mutation }\end{array}$ & $\begin{array}{c}\text { Galactose-free diet } \\
\text { Oestrogen from 12-13 } \\
\text { years; then + progestins } \\
\text { Discuss recombinant } \\
\text { FSH/oocyte } \\
\text { cryopreservation } \\
\text { Osteoporosis: Calcium } \pm \\
\text { vitamin D } \pm \\
\text { diphophonates }\end{array}$ \\
\hline \multicolumn{5}{|l|}{$\begin{array}{c}\text { Complex molecules } \\
\text { disorders }\end{array}$} \\
\hline $\begin{array}{c}\text { X-linked } \\
\text { adrenoleukodystrophy }\end{array}$ & $\begin{array}{l}\text { Progressive central } \\
\text { and peripheral } \\
\text { nervous system } \\
\text { demyelination } \\
\text { in boys }\end{array}$ & $\begin{array}{c}\text { Clinical hypogonadism: } \mathbf{2 / 3} \\
\text { Erectile dysfunction: } 58 \% \\
\text { Small testes: } 12 \% \\
\text { Primary adrenal failure involving both gluco and } \\
\text { mineralosteroid: } 70 \% \text { in adults }\end{array}$ & $\begin{array}{c}\text { Low } \\
\text { testosterone12\% } \\
\text { Inadequate } \\
\text { response to HCG: } \\
\mathbf{8 8 \%} \\
\text { High LH:16\% and } \\
\text { FSH levels: } 32 \% \\
\text { High testosterone/ } \\
\text { DHT ratio } \\
\text { High VLCFA } \\
\text { Leukocytes } A B C D \text { 1 } \\
\text { gene mutation }\end{array}$ & $\begin{array}{l}\text { Lorenzo oil } \\
\text { Blood marrow } \\
\text { transplantation } \\
\text { Gene therapy }\end{array}$ \\
\hline $\begin{array}{l}\text { Perrault syndrome or } \\
\text { D-bifunctional protein } \\
\text { deficiency }\end{array}$ & $\begin{array}{l}\text { Hearing loss } \\
\text { Ataxia }\end{array}$ & Ovarian dysgenesis & $\begin{array}{l}\text { Leukocyte HSD17 } \beta 4 \\
\text { gene mutation, } \\
\text { Sometimes } \\
\text { mitochondrial DNA } \\
\text { mutation }\end{array}$ & \\
\hline $\begin{array}{l}\text { Congenital disorders } \\
\text { of glycosylation } \\
\text { Most are protein } \\
\text { hypoglycosylation } \\
\text { diseases }\end{array}$ & $\begin{array}{l}\text { Affect nearly all } \\
\text { organs and systems } \\
\text { Often a significant } \\
\text { neurological } \\
\text { component. }\end{array}$ & $\begin{array}{c}\begin{array}{c}\text { Hypogonadism with small testes or } \\
\text { amenorrhea }\end{array} \\
\text { Hypo-, hypergonadotropic or mixed } \\
\text { hypogonadism } \\
\text { Sometimes hyperprolactinaemia } \\
\text { Abnormal TSH } \\
\text { Insulin resistance related to peculiar fat } \\
\text { repartition }\end{array}$ & $\begin{array}{l}\text { N-glycosylation } \\
\text { diseases: } \\
\text { serum transferrin } \\
\text { isoelectrofocusing } \\
\text { O-glycosylation } \\
\text { disorders: } \\
\text { apo Clll } \\
\text { isoelectrofocusing } \\
\text { Leukocytes gene } \\
\text { mutation }\end{array}$ & $\begin{array}{l}\text { Inhibitors of } \\
\text { phosphomannose } \\
\text { isomerase under } \\
\text { evaluation in CDG-la } \\
\text { Mannose in CDG-lb }\end{array}$ \\
\hline Cystinosis & $\begin{array}{l}3 \text { forms: infantile, } \\
\text { juvenile, ophthalmic } \\
\text { (adulthood) } \\
\text { Liver and muscle } \\
\text { involvement } \\
\text { Progression to end- } \\
\text { stage renal disease }\end{array}$ & $\begin{array}{c}\text { Hypergonadotropic hypogonadism } \mathbf{7 4 \%} \text { in } \\
\text { males (gonadotropin levels above the normal } \\
\text { range and testosterone levels in the low normal } \\
\text { range); Delayed puberty } \\
\text { Hypothyroidism }>50 \% \\
\text { Insulin-dependant diabetes } \\
\text { Growth failure }\end{array}$ & $\begin{array}{l}\text { Gluco-phospho- } \\
\text { aminic diabetes } \\
\text { Hypokalaemia, } \\
\text { acidosis, } \\
\text { Leukocyte cystin } \\
\text { measurement } \\
\text { CTNS gene mutation }\end{array}$ & $\begin{array}{l}\text { Electrolyte } \\
\text { supplementation } \\
\text { Vitamins } \\
\text { Indomethacin } \\
\text { Cysteamine }\end{array}$ \\
\hline Fabry disease & $\begin{array}{l}\text { Acroparaesthesias in } \\
\text { boys } \\
\text { Angiokeratoma } \\
\text { Stroke at young age } \\
\text { Renal, heart and eye } \\
\text { involvement }\end{array}$ & $\begin{array}{c}\text { Hypothyroidism } \\
\text { Isolated case report of subclinical adrenal } \\
\text { insufficiency and hypoparathyroidism } \\
\text { Infertility, osteoporosis }\end{array}$ & $\begin{array}{l}\text { Alpha-galactosidase } \\
\text { A in males } \\
\text { GLA gene mutation } \\
\text { in females (X-linked) }\end{array}$ & $\begin{array}{l}\text { Substitutive recombinant } \\
\text { enzyme therapy }\end{array}$ \\
\hline
\end{tabular}


Table 4 Main IEM associated with hypogonadism (Continued)

\begin{tabular}{|c|c|c|c|c|}
\hline Alström syndrome & $\begin{array}{l}\text { Short height } \\
\text { Renal failure } \\
\text { Dilated } \\
\text { myocardiopathy } \\
\text { Blindness, Deafness }\end{array}$ & $\begin{array}{c}\text { Early insulin resistant diabetes - Childhood } \\
\text { obesity } \\
\text { Primary hypogonadism (in males) } \\
\text { PCOS and hirsutism in female } \\
\text { Hypothyroidism }\end{array}$ & $\begin{array}{c}\text { Major } \\
\text { Hypertriglyceridaemia } \\
\text { HypoHDLemia } \\
\text { Leukocytes ALMS / } \\
\text { gene mutation }\end{array}$ & \\
\hline $\begin{array}{l}\text { Selenoprotein } \\
\text { deficiency disorder }\end{array}$ & $\begin{array}{c}\text { Myopathy, } \\
\text { Dermal } \\
\text { photosensitivity }\end{array}$ & Oligospermia & $\begin{array}{l}\text { low serum T3 and } \\
\text { and high serum T4 } \\
\text { Reduced } \\
\text { selenoprotein } \\
\text { concentrations } \\
\text { Leukocytes SECISBP2 } \\
\text { gene mutation }\end{array}$ & $\begin{array}{l}\text { Selenium } \\
\text { supplementation not } \\
\text { efficient on hormone } \\
\text { thyroid profile }\end{array}$ \\
\hline \multicolumn{5}{|l|}{ Energy defect } \\
\hline $\begin{array}{l}\text { Mitochondrial } \\
\text { cytopathies }\end{array}$ & $\begin{array}{c}\text { See Table } 2 \text { or } 3 \\
\text { Maternal inheritance }\end{array}$ & $\begin{array}{l}\text { Hypogonadotropic hypogonadism: 20\% t- 30\% } \\
\text { delayed growth and puberty }\end{array}$ & See Table 2 or 3 & See Table 2 or 3 \\
\hline Glycogenosis & $\begin{array}{l}\text { Liver involvement } \\
\text { Infections in type Ib } \\
\text { Renal complications } \\
\text { in adulthood }\end{array}$ & $\begin{array}{c}\text { Children: fasting ketosis hypoglycaemia; growth } \\
\text { failure } \\
\text { Adults: I, III types: polycystic ovary syndrome, } \\
\text { diabetes, osteoporosis } \\
\text { VI, IX types: spontaneous recovering delayed } \\
\text { puberty } \\
\text { autoimmune hypothyroidism in type I b }\end{array}$ & $\begin{array}{c}\text { hyperlipaemia, } \\
\text { hyperlactataemia, } \\
\text { hyperuricaemia } \\
\text { Leukocytes gene } \\
\text { mutation }\end{array}$ & $\begin{array}{c}\text { Frequent food intake, } \\
\text { uncooked cornstarch } \\
\text { Low carbohydrate } \\
\text { glycaemic index } \\
\text { Night enteral feeding } \\
\text { G-CSF in Ib type, } \\
\text { allopurinol } \\
\text { Avoid oestroprogestative } \\
\text { pills }\end{array}$ \\
\hline
\end{tabular}

All autosomal recessive unless otherwise indicated

Abbreviations: DHT: Dihydrotestosterone; G-CSF: Granulocyte colony-stimulating factor; GALT: galactose-1-phosphate uridyltransferase; HSD17B4: 17betahydroxysteroid dehydrogenase type 4 (also known as D-bifunctional protein (DBP). PCOS: Polycystic ovary syndrome; VLCFA: Very long chain fatty acids.

Hypothyroidism may also induce anomalies in $ß$ cell development, showing the interrelations between the different hormonal axes [44].

\section{Energy metabolism defects}

Mitochondrial cytopathies, especially Kearns-Sayre and MELAS syndromes, have been reported to be the cause of primary dysthyroidism in several publications, three cases of which were autoimmune hyperthyroidism [8,9,45-48]. Given the frequency of autoimmune dysthyroidism in the general population, a fortuitous association between mitochondrial cytopathies and thyroidopathies cannot be ruled out. Indeed, A3243G mitochondrial mutation does not actually occur significantly more often in patients with autoimmune diseases. We personally observed one-third of cases with hypothyroidism, 50\% of which displayed a goiter or a pituitary component in a series of respiratory deficient patients (unpublished observation). Testing should always be done for both origins. Thyrotropic insufficiency is probably underestimated. Energy defects could impair thyroperoxidase, lowering the production of thyroid hormones, which themselves are involved in mitochondrial metabolism, therefore worsening the mitochondrial dysfunction.

Glycogen storage disease: An increased prevalence of autoimmune hypothyroidism has been found in type Ib glycogenosis (glucose-6-phospate translocase defect)
(ORPHA79259); however, patients with the type Ia form (glucose-6 phosphatase defect) (ORPHA79258) had a low frequency of thyropathies in a series of patients with glycogenosis (10 with type 1a and 7 with type Ib) compared to 34 matched controls [49]. FT4 blood levels were significantly lower in both type Ia and Ib than in the control group, whereas TSH, thyroglobulin levels and antithyroperoxidase antibodies were higher only in patients with type Ib. Central impairment may be associated with these anomalies, since the increase of TSH level always remains mild. Indeed, glucose-6-phosphatase defect inducing glycogen accumulation has been observed in the pituitary, adrenal, thyroid, parathyroid, and pancreatic glands. Otherwise, most GSD Ib patients also show neutropaenia and therefore are at risk of developing infections and autoimmune-related disorders.

\section{Degradation or synthesis of complex molecules}

Fabry disease is an X-linked lysosomal disease related to an alpha-galactosidase A deficiency, which induces an accumulation of globotriaosylceramide. Mild forms of the disorder may appear later in life and affect only the heart or kidneys. Subclinical, non-autoimmune hypothyroidism was observed in $4 / 11$ cases in an untreated series, and in 3 cases associated with adrenal and gonadal disturbances in another series of 18 patients, 10 of whom were being treated with substitutive enzyme therapy $[50,51]$. Osteopenia was frequent. 
Subclinical primary hypothyroidism has been shown to improve after long-term enzyme replacement therapy [52].

Cystinosis was complicated by hypothyroidism in $75 \%$ of patients [32-34].

Type 1 hyperoxaluria (< 1-9/1000000, ORPHA93598) is induced by a liver peroxisomal deficiency secondary to alanine glyoxylate aminotransferase gene mutations [53]. Several cases of hypothyroidism revealing or complicating this renal disease have been reported, without any significance as to the age of the patient $[54,55]$. Hypothyroidism is usually severe, probably linked to the tissular accumulation of calcium oxalate, but also to immunoreactivity deficiency and sensitivity to proteasomal degradation induced by impaired dimerization in the mutated gene variants.

Neutral lipid storage disease (< 1/1000000, ORPHA155): This rare non-lysosomal lipid storage disorder is caused by defects in two triglyceride-associated proteins: adipose triglyceride lipase, encoded by the gene "patatin-like phospholipase domain-containing 2" (PNPLA2); and "alpha/ß-hydrolase domain-containing protein 5", encoded by the ABHD 5 gene, also called "comparative gene identification-58". Dysfunction of these two proteins affects the degradation of triglycerides, and then causes their accumulation in cells with two different phenotypes [56]. Thyroid nodular dystrophy related to intracellular accumulation of triglycerides has been reported in lipid storage disease with the "ichtyosis" phenotype [57] (see Table 3).

MCT8 deficiency: This X-linked mental retardation syndrome in male subjects involves the transport of triiodothyronine into neurons with high $\mathrm{T}_{3}$ and inadequately low T4 and fT4 concentration [58]. This biological effect persists after complete thyroidectomy and substitution with levothyroxine, which involves peripheral deiodination. Progressive thyroid follicular dystrophy with a possible risk of papillary carcinoma has been recently reported [59]. Heterozygous MCT8 women, usually asymptomatic, should be monitored for the requirement of L-T4 therapy to prevent fetal and neonatal hypothyroidism $[58,60]$. In families at risk, a prenatal diagnosis for male fetuses can be done. Treatment with propylthiouracile and L-thyroxine has been proposed [61].

Congenital disorder of glycosylation: Thyroid function tests are frequently abnormal in children with CDG; congenital hypothyroidism has been suspected. However, free thyroxine analyzed by equilibrium dialysis, the most accurate method, was reported as normal in seven individuals with CDG [62]. In contrast, CDG are associated with hypogonadism and are detailed in this section.
Selenoprotein deficiency disorder (ORPHA209193): Selenium is a micronutrient involved in selenoprotein metabolism, such as the glutathione peroxidase, mediating the removal of cellular reactive oxygen species, and deiodinases, which are involved in thyroxine metabolism. Mutations in the SECISBP2 (Sec insertion sequence-binding protein 2, also known as SBP2) gene result in reduced synthesis of all selenoproteins, and have a multisystem expression with an abnormal thyroid hormone profile (low T3, high T4) [63,64]. Selenium supplementation fails to correct the selenoprotein synthesis defect in subjects with SBP2 gene mutations [65].

Haemochromatosis: A case of a 56-year-old male patient with haemochromatosis complicated by cirrhosis, insulin-dependent diabetes and hypogonadism with regressive hypothyroidism after venopuncture has recently been reported [66]. Nevertheless, in two studies of 100 to 200 homozygote $C 282 Y$ patients, the prevalence of hypo- and hyperthyroidism that was below $1 \%$ did not differ from that of the control group [67]. Dysthyroidism was however more frequent in acquired haemochromatosis.

In conclusion, dysthyroidism may complicate energy metabolism diseases (respiratory chain defect, GSD) or organelle disorders affecting mainly the kidney (cystinosis, type I hyperoxaluria) or selectively the thyroid gland (MCT8 and selenoprotein deficiencies).

\section{Hypogonadism}

Medical advances have enabled the survival of patients suffering from IEM. Nevertheless, hypogonadism remains one of the most frequent complications in adolescence. Optimization of pubertal progress should reduce the impact of growth retardation, later adult bone loss and related psychosocial issues. Screening for primary or hypogonadotrophic hypogonadism, as well as osteoporosis, should be done in adulthood.

\section{Intoxication disorders}

Haemochromatosis: Hypogonadotropic hypogonadism was found in $5.2 \%$ of a series of 38 female patients and $6.4 \%$ of a series of 141 male subjects, $89 \%$ of whom also had cirrhosis and 33\% diabetes [68]. This prevalence of hypogonadism had been previously evaluated at $40 \%$, with this fact being linked to an earlier diagnosis and treatment. In another series of 87 patients with hereditary hemochromatosis, osteoporosis was detected in $25 \%$ and osteopenia in $41 \%$. Bone mineral density was independently associated with body mass index, hypogonadism/menopause, and the amount of iron removed to reach depletion [69]. Furthermore, haemochromatosis should always be suspected in male subjects with isolated hypogonadotropic hypogonadism. In young men, 
the diagnosis of juvenile haemochromatosis, despite its rarity, should be considered, especially in case of cardiac involvement. At least three Japanese men bearing new mutations of the HJV (hemojuveline) gene, which is usually found in so-called "juvenile" haemochromatosis, were diagnosed in their fifties due to hypogonadism, showing the wide variability of the phenotype [70]. Pituitary iron overload, as well as the HFE and transferrin genotype, may explain the hypothalamic-pituitarygonadal involvement [71]. If diagnosed early, hypogonadism can regress after phlebotomy. The treatment with androgens might be difficult considering the increased risk of hepatocarcinoma when associated with cirrhosis and the potential carcinogenic role of androgen therapy [72].

Classical galactosemia is a not so rare disorder of galactose metabolism. Despite a strict diet and newborn screening, long-term complications usually include mental retardation, cataracts and ovarian insufficiency in most girls [73]. Indeed, in a series of 34 female patients aged 17 to 51 years, only 4 menstruated regularly without any treatment, and a single pregnancy occurred spontaneously [74]. In another series of 33 patients (16 women), all female subjects had ovarian insufficiency. One woman and two men had children. The genotype does not seem to predict the chances of becoming pregnant $[73,74]$. During pregnancy, elevations in galactose metabolites do occur but without evidence of clinical impact on the mother or child, although possible longterm effects have not been thoroughly investigated [75].

Many mechanisms are involved including: 1) an accumulation of galactose-1-phosphate, which induces a rapid loss of follicles through cellular apoptosis, and of galactitol, which alters the ovarian tissue; and 2) a deficiency in UDP-galactose, which alters glycosylation, possibly impairing FSH activity [76-79]. Hypoglycosylation is diet-dependent and may worsen when galactose intake increases either because of poor compliance or unrestricted diet.

Currently, haemochromatosis and galactosemia are the two main intoxication diseases that are complicated by hypogonadism. In contrast with iron overload, in which hypogonadism can be prevented or improved through treatment, hypogonadism in female patients with galactosemia is a unique endocrine complication and occurs in most patients despite early prospective treatment.

\section{Organelle disorders involving the synthesis or degradation of complex molecules} $X$-Adrenoleukodystrophy (X-ALD) and D-bifunctional protein (D-BF) deficiency (ORPHA300): X-ALD is a progressive peroxisomal disorder affecting adrenal glands, testes and myelin stability caused by mutations in the $A B C D 1$ gene, which encodes for ALD protein. The anomalies of this peroxisomal transporter induce a ß-oxidation defect of VLCFA $[80,81]$. X-ALD is associated in more than two-thirds of cases with clinical hypogonadism and anomalies of the gonadotropic axis [82]. Severe impairment of spermatogenesis and rapid progression to azoospermia were reported despite normalization of plasma VLCFA concentrations in a postpubertal patient [83]. Oxidative stress plays a role, at least in the neurodegeneration features [84]. Otherwise, although D-BF protein deficiency is in general a severe neonatal or infantile disease mimicking the peroxisome biogenesis or so-called Zellweger spectrum disorders $[85,86]$, two siblings with Perrault syndrome were reported with mutations in the D-BP (HSD17 $\beta 4)$ gene [87]. However, other patients with Perrault syndrome had no mutations in this gene, indicating that this syndrome is genetically heterogeneous and is sometimes related to mutations of mitochondrial DNA [88].

Congenital disorders of glycosylation (CDG) are a rapidly growing group of diseases that impair protein glycosylation, one of the major functions occurring in the endoplasmic reticulum and Golgi compartments [89]. The clinical manifestations are heterogeneous $[90,91]$. Elevated tissue fibrosis, frequent in CDG patients, could promote hypogonadism, which is frequent, especially in males [92-97]. Varying hormonal profiles and degrees of virilization in CDG females suggest a spectrum of yet unidentified mechanisms affected by impaired N-glycosylation [98]. Potential treatment of the most common form, CDG-Ia, with phosphomannose isomerase inhibitors is under evaluation [99].

Cystinosis: The onset of puberty was consistently delayed in a series of 17 patients with chronic renal insufficiency [100]. Hypergonadotropic hypogonadism has been found in $50 \%$ to $75 \%$ of males. It seems to be related to fibrosis and testicular atrophy and promotes growth retardation $[33,34,100]$.

Fabry disease: $89 \%$ of women may have menstrual disorders (or spontaneous abortions), although gonadotropic stimulation tests were normal in women; oligo/ asthenozoospermia is frequently found in males $[51,101]$.

Alström disease: The most common endocrinological manifestation besides type 2 diabetes is hypogonadism. In a series of 182 patients (83 males) [28], hypergonadotropic and hypogonadotropic hypogonadism were common in males (77\%). Puberty was often delayed, but masculinization and secondary sexual characteristics in adult males were normal. Basal testosterone levels were frequently diminished for age with increased baseline luteinizing hormone/follicle-stimulating hormone levels typical of primary gonadal failure. Gynecomastia was present in 37\% of males, as was cryptorchidism in $0.02 \%$ of cases. The mean 
menarchal age was 12.6 years. Endocrine disturbances were observed in $54 \%$ of 78 females and included hirsutism, abnormal breast development, cystic ovaries, precocious puberty (pubertal onset at age $<8$ years), endometriosis, irregular menses and amenorrhea.

Finally, peroxysomal, lysosomal and reticulum endoplasmal disorders are frequently associated with manifestations such as delayed onset of puberty, hypogonadism and infertility, as well as other endocrine disorders. Their responsiveness to treatment has not been fully investigated up till now.

\section{Energy metabolism disorders}

Mitochondrial cytopathies: Hyper- [88,102] and hypogonadotropic $[9,103-105]$ hypogonadism have been described in case reports [106], but the frequency can reach $20 \%$ in patients with Kearns-Sayre syndrome [45]. Anomalies of estrogen metabolism in the muscle have also been reported in these patients who often have a myopathic component $[107,108]$.

In a series with glycogen storage disease, both type I $(\mathrm{n}=13)$ and type III $(\mathrm{n}=14)$, all patients older than 4.8 years presented with polycystic ovary syndrome but without hormonal biological disturbances, except hyperinsulinaemia [109]. Delayed puberty-related growth impairment and short stature have also been described. The role of glucose metabolism alteration is probably involved in the ovarian pathophysiology.

Finally, hypogonadism is a less frequent complication of energy metabolism disorders than of organelle disorders.

In conclusion with regard to hypogonadism, most IEMs can be complicated by hypogonadism, but classical galactosemia and organelle disorders are the most frequently involved diseases. Except for iron overload, in which hypogonadism might be prevented or improved with iron depletion, the mechanisms are not yet fully understood and causal treatment remains difficult.

\section{Adrenal failure}

As with thyroid hormones, steroids are liposoluble hormones, and adrenal insufficiency has mainly been reported in adrenoleukodystrophy (X-ALD) and energy metabolism defects.

$X$-adrenoleukodystrophy, the most common cause of primary adrenal failure in IEM, is associated with neurological symptoms $[80,81]$. In adulthood, adrenal insufficiency, which generally appears after the age of 3-4 years, is present in $70 \%$ of patients. It can be the first and only manifestation of the disease for decades. Its association with neuropathy suggests the diagnosis. At age 20 years, it is usually associated with hypergonadotropic hypogonadism.
Fabry disease: Patients with Fabry disease have been found to have lower mean cortisol plasma levels than in controls. Partial adrenal insufficiency was observed after the $31-24$ corticotrophin test in only one of the $18 \mathrm{stu}-$ died patients [51]. These data need to be confirmed since acute adrenal failure has never been reported before.

Niemann-Pick disease (< 1-9/100000, ORPHA645) is a lysosomal lipid storage disease caused by mutations in the sphingomyelin phosphodiesterase 1 (SMPD1) gene, which results in the deficient activity of lysosomal acid. Partial adrenal insufficiency has been reported in type B, a non-neurologic, visceral form with hepatosplenomegaly, pulmonary disease and survival into adolescence and/or adulthood [110].

Mitochondrial cytopathies: Adrenal failure is rare in childhood but might reveal the presence of the disease [111], thus being a poor prognostic factor [112-114]. In adulthood, subclinical adrenocortical insufficiency is sometimes found in multisystemic forms [115]. Various types of aldosterone secretion disturbances, mainly secondary hyperaldosteronism possibly linked to tubulopathies, have also been reported $[45,116]$.

\section{Hypoparathyroidism}

Hypoparathyroidism may occur, though rarely, in all types of IEM, the most frequent being mitochondrial cytopathies [117-119].

Hypoparathyroidism might also complicate acquired iron overload in major thalassemia [120], and occasionally adrenoleukodystrophy, and Fabry or Wilson's disease (< 1-9/100000, ORPHA905), a congenital disorder of copper metabolism affecting the hepatic and nervous systems $[121,122]$.

In fatty acid oxidation (FAO) disorders, and particularly in LCHAD (long-chain 3-hydroxyacyl-coenzyme A dehydrogenase) deficiency (<1-9/100000, ORPHA5) and trifunctional enzyme defects, which are characterized by neuropathy and retinopathy, transient hypoparathyroidism occurs frequently in cases of acute decompensation and is usually asymptomatic $[123,124]$. Later-onset exercise-induced myopathic symptoms remain characteristic clinical features of FAO disorders, in addition to heart and liver involvement.

\section{Hypopituitarism and growth}

Pituitary assessment has not been systematically done in IEM. Relative problems could go partially unrecognized due to the difficulty of the evaluation in subclinical forms and the possible mixed primary and pituitary involvement. Otherwise short stature might also be multifactorial due to liver or renal dysfunction, poor nutritional status or psychosocial issues. 
A few cases of hypopituitarism and diabetes insipidus [19] have been reported in mitochondrial cytopathies $[9,45,103,104]$ and iron overload [125-127].

Growth retardation was found in $30 \%$ to $60 \%$ of mitochondrial cytopathies, cystinosis [34] and galactosemia [128]. The resulting short stature is also found in Niemann-Pick disease [110] and Alström syndrome [28].

However, Alström syndrome is associated with advanced bone age, and normal early growth may be due to hyperinsulinism $[28,129,130]$, although in a series of 15 patients, no significant relation was observed between IGF (Insulin Growth Factor) levels and body mass index or blood glucose, insulin and testosterone levels [131]. Type 1 hyperoxaluria is also associated with advanced skeletal age in young patients, increased FGF23 (Fibroblast Growth Factor 23) levels and decreased bone mineral density, thus promoting fractures [132]. Further investigations, including GH (Growth Hormone) dynamics, are needed to determine whether disturbances in the GH/IGF axis contribute to this relatively short stature, the origin of which is probably multifactorial through decreased renal function, feeding difficulties, hypothyroidism, hypogonadism, etc.

\section{Conclusion}

With the exception of iron overload, IEM are very rare disorders. They may be associated with endocrine disorders, most of which are linked to carbohydrate metabolism disturbances, thyroid dysfunction and hypogonadism. The endocrinologist may screen patients with a diagnosis that was established in childhood for complications. In rarer cases, the diagnosis of IEM should be suspected when there are multiple endocrinopathies or when there is associated multisystemic injury. A prospective investigation of endocrine function should probably be scheduled in IEM, since numerous asymptomatic endocrine disorders with delayed manifestations have been found. Indeed, the long-term consequences of IEM on fertility and bone are still poorly understood. Mechanisms such as energy required for hormonal synthesis, toxic accumulation of a metabolite, hormone transportation defect or hormone/receptor glycosylation should be better investigated in order to improve our understanding of the pathophysiology and to help innovate in the screening and treatment of endocrine disorders. A few biological exams relying on baseline blood and urine sampling can steer the diagnosis. Consultation with a specialist is usually required in reference centers, with whom it is often necessary to collaborate.

\section{List of abbreviations}

ABHD5: alpha/ß-hydrolase domain-containing protein 5; AGTX: Alanineglyoxylate-aminotransferase gene; ATGL: Adipose triglyceride lipase; CDG: congenital disorders of glycosylation; CPK: creatin phospho kinase; CSF: cerebrospinal fluid; DBP: D-bifunctional protein; DHT: Dihydrotestosterone DIDMOAD: Diabetes Insipidus, Diabetes Mellitus, Optic Atrophy, and Deafness; FGF23: Fibroblast Growth Factor 23; GALT: galactose-1-phosphate uridyltransferase; G-CSF: Granulocyte colony-stimulating factor; GH: Growth hormone; G-6-P: glucose-6-phosphatase

GSD: glycogen storage diseases; HSD17B4: 17ß-hydroxysteroid dehydrogenase type 4; IEM: inborn errors of metabolism; IGF: Insulin Growth Factor; LCHAD: long-chain 3-hydroxyacyl-CoA dehydrogenase deficiency; MCT8: Monocarboxylate Transporter 8; MELAS: Myopathy, Encephalopathy, Lactic Acidosis, Stroke; MIDD: Maternal Inherited Diabetes Deafness; MODY: Maturity Onset Diabetes of the Young; PCOS: polycystic ovary syndrome; PNPLA2: patatin-like phospholipase domain containing 2; reverse T3 or rT3: 3,3', '5'-triiodothyronine; SECISBP2: Sec insertion sequence-binding protein 2; SMPD1: sphingomyelin phosphodiesterase 1; T3: 3,3',5-triiodothyronine; T4 or thyroxine: tetraiodothyronine; VLCFA: Very long chain fatty acids; X-ALD: Xlinked adrenoleukodystrophy

\section{Author details}

${ }^{1}$ Service d'Endocrinologie et Maladies Métaboliques, 1, Rue Polonovski, Hôpital C Huriez., Centre Hospitalier Régional et Universitaire de Lille, 59037 Lille cedex, France. ${ }^{2}$ Centre de Référence des Erreurs Innées du Métabolisme -Hôpital Jeanne de Flandres, Centre Hospitalier Régional et Universitaire de Lille, 59037 Lille cedex, France. ${ }^{3}$ Département des Maladies Métaboliques, Fédération des Maladies du Système Nerveux, Hôpital Pitié-Salpêtrière, Assistance Publique Hôpitaux de Paris et Université Pierre et Marie Curie (Paris VI), France.

\section{Authors' contributions}

MCV, CD and JMS wrote and coordinated the writing of the manuscript; KM DD and JLW participated in the design of the review and helped to draft the manuscript. All the authors read and approved the final manuscript.

\section{Competing interests}

The authors declare that they have no competing interests.

Received: 16 October 2011 Accepted: 28 January 2012

Published: 28 January 2012

\section{References}

1. Saudubray JM, Sedel F: Inborn errors of metabolism in adults. Ann Endocrinol (Paris) 2009, 70:14-24.

2. Brissot $P$, Bardou-Jacquet $E$, Troadec MB, Mosser A, Island ML, Detivaud L, Loréal O, Jouanolle AM: Molecular diagnosis of genetic iron-overload disorders. Expert Rev Mol Diagn 2010, 10:755-763.

3. Vantyghem MC, Fajardy I, Dhondt F, Girardot C, D'Herbomez M, Danze PM, Rousseaux J, Wemeau JL: Phenotype and HFE genotype in a population with abnormal iron markers recruited from an Endocrinology Department. Eur J Endocrinol 2006, 154:835-841.

4. Ogimoto M, Anzai K, Takenoshita H, Kogawa K, Akehi Y, Yoshida R, Nakano M, Yoshida K, Ono J: Criteria for early identification of aceruloplasminemia. Intern Med 2011, 50:1415-1418.

5. Fasano A, Colosimo C, Miyajima H, Tonali PA, Re TJ, Bentivoglio AR: Aceruloplasminemia: a novel mutation in a family with marked phenotypic variability. Mov Disord 2008, 23:751-755.

6. Yatsuga S, Povalko N, Nishioka J, Katayama K, Kakimoto N, Matsuishi T, Kakuma T, Koga Y, Taro Matsuoka for MELAS Study Group in Japan: MELAS: A nationwide prospective cohort study of 96 patients in Japan. Biochim Biophys Acta 2011

7. Schiff M, Loublier S, Coulibaly A, Benit P, Ogier de Bauny H, Rustin P: Mitochondria and diabetes mellitus: unstangling a conflictive relationship? J Inher Metab Dis 2009, 32:684-698.

8. Balestri P, Grosso S: Endocrine disorders in two sisters affected by MELAS syndrome. J Child Neurol 2000, 15:755-758.

9. Sadikovic B, Wang J, El-Hattab A, Landsverk M, Douglas G, Brundage EK Craigen WJ, Schmitt ES, Wong LJ: Sequence homology at the breakpoint and clinical phenotype of mitochondrial DNA deletion syndromes. PLOS One 2010, 5(12):e15687.

10. Massin P, Dubois-Laforgue D, Meas T, Laloi-Michelin M, Gin H, Bauduceau B, Bellanné-Chantelot C, Bertin E, Blickle JF, Bouhanick B, Cahen-Varsaux J, Casanova S, Charpentier G, Chedin P, Dupuy O, Grimaldi A, Guerci B, Kaloustian E, Lecleire-Collet A, Lorenzini F, Murat A, Narbonne H, Olivier F, 
Paquis-Flucklinger V, Virally M, Vincenot M, Vialettes B, Timsit J, Guillausseau PJ, GEDIAM (Mitochondrial Diabetes French Study Group): Retinal and renal complications in patients with a mutation of mitochondrial DNA at position 3,243 (maternally inherited diabetes and deafness) A case-control study. Diabetologia 2008, 51:1664-1670.

11. Kobayashi T, Nakanishi K, Nakase H, Kajio H, Okubo M, Murase T, Kosaka K: In situ characterization of islets in diabetes with a mitochondrial DNA mutation at nucleotide position 3243. Diabetes 1997, 46:1567-1571.

12. Lightfoot $\mathrm{YL}$, Chen J, Mathews CE: Role of the Mitochondria in ImmuneMediated Apoptotic Death of the Human Pancreatic $\beta$ Cell Line $\beta$ Lox5. PLoS One 2011, 6:e20617.

13. Suzuki S, Hinokio $Y$, Hirai S, Onoda M, Matsumoto M, Ohtomo M, Kawasaki H, Satoh Y, Akai H, Abe K, and al: Pancreatic ß-cell secretory defect associated with mitochondrial point mutation of the tRNA (LEU (UUR)) gene: a study in seven families with mitochondrial encephalomyopathy, lactic acidosis and stroke-like episodes (MELAS). Diabetologia 1994, 37:818-825.

14. Cook DL, Hales CN: Intracellular ATP directly blocks K+ channels in pancreatic B-cells. Nature 1984, 311:271-273.

15. Lindroos MM, Majamaa K, Tura A, Mari A, Kalliokoski KK, Taittonen MT, Iozzo P, Nuutila P: The m.3243A > G mutation in mitochondrial DNA leads to decreased insulin sensitivity in skeletal muscle and to progressive $\beta$-cell dysfunction. Diabetes 2009, 58:543-549.

16. Laloi-Michelin M, Meas T, Ambonville C, Bellanné-Chantelot C, Beaufils $S$ Massin P, Vialettes B, Gin H, Timsit J, Bauduceau B, Bernard L, Bertin E, Blickle JF, Cahen-Varsaux J, Cailleba A, Casanova S, Cathebras P, Charpentier G, Chedin P, Crea T, Delemer B, Dubois-Laforgue D, Duchemin F, Ducluzeau PH, Bouhanick B, Dusselier L, Gabreau T, Grimaldi A Guerci B, Jacquin V, Kaloustian E, Larger E, Lecleire-Collet A, Lorenzini F, Louis J, Mausset J, Murat A, Nadler-Fluteau S, Olivier F, Paquis-Flucklinger V, Paris-Bockel D, Raynaud I, Reznik Y, Riveline JP, Schneebeli S, Sonnet E, SolaGazagnes A, Thomas JL, Trabulsi B, Virally M, Guillausseau PJ: Mitochondrial Diabetes French Study Group: The clinical variability of maternally inherited diabetes and deafness is associated with the degree of heteroplasmy in blood leukocytes. J Clin Endocrinol Metab 2009, 94:3025-3030.

17. Karicheva OZ, Kolesnikova OA, Schirtz T, Vysokikh MY, Mager-Heckel AM, Lombès A, Boucheham A, Krasheninnikov IA, Martin RP, Entelis N, Tarassov I: Correction of the consequences of mitochondrial 3243A > G mutation in the MT-TL1 gene causing the MELAS syndrome by tRNA import into mitochondria. Nucleic Acids Res 2011, 39:8173-86.

18. Mezghani N, Mnif M, Mkaouar-Rebai E, Kallel N, Salem IH, Charfi N, Abid M, Fakhfakh F: The mitochondrial ND1 m.3337G > A mutation associated to multiple mitochondrial DNA deletions in a patient with Wolfram syndrome and cardiomyopathy. Biochem Biophys Res Commun 2011, 411:247-52.

19. Cryns K, Sivakumaran TA, Van den Ouweland JM, Pennings RJ, Cremers CW, Flothmann K, Young TL, Smith RJ, Lesperance MM, Van Camp G: Mutational spectrum of the WFS1 gene in Wolfram syndrome, nonsyndromic hearing impairment, diabetes mellitus, and psychiatric disease. Hum Mutat 2003, 22:275-287.

20. Noormets K, Kõks S, Muldmaa M, Mauring L, Vasar E, Tillmann V: Sex differences in the development of diabetes in mice with deleted wolframin (WFS1) gene. Exp Clin Endocrinol Diabetes 2011, 119:271-275.

21. Hartemann-Heurtier A, Simon A, Bellanné-Chantelot C, Reynaud R, Cavé H, Polak M, Vaxillaire M, Grimaldi A: Mutations in the ABCC8 gene can cause autoantibody-negative insulin-dependent diabetes. Diabetes Metab 2009, 35:233-235.

22. Klupa T, Kowalska I, Wyka K, Skupien J, Patch AM, Flanagan SE, Noczynska A, Arciszewska M, Ellard S, Hattersley AT, Sieradzki J, Mlynarski W, Malecki MT: Mutations in the ABCC8 (SUR1 subunit of the K(ATP) channel) gene are associated with a variable clinical phenotype. Clin Endocrinol (Oxf) 2009, 71:358-362.

23. Kapoor RR, Flanagan SE, James CT, McKiernan J, Thomas AM, Harmer SC, Shield JP, Tinker A, Ellard S, Hussain K: Hyperinsulinaemic hypoglycaemia and diabetes mellitus due to dominant $A B C C 8 / K C N J 11$ mutations. Diabetologia 2011, 54:2575-83.

24. Irimia JM, Meyer CM, Peper CL, Zhai L, Bock CB, Previs SF, McGuinness OP DePaoli-Roach A, Roach PJ: Impaired glucose tolerance and predisposition to the fasted state in liver glycogen synthase knock-out mice. J Biol Chem 2010, 285:12851-12861.
25. Spiegel R, Rakover-Tenenbaum Y, Mandel H, Lumelski D, Admoni O, Horovitz Y: Secondary diabetes mellitus: late complication of glycogen storage disease type 1b. J Pediatr Endocrinol Metab 2005, 18:617-619.

26. Oki Y, Okubo M, Tanaka S, Nakanishi K, Kobayashi T, Murase T: Diabetes mellitus secondary to glycogen storage disease type III. Diabet Med 2000, 17:810-812.

27. Ismail H: Glycogen storage disease type III presenting with secondary diabetes and managed with insulin: a case report. Cases J 2009, 2:6891.

28. Marshall JD, Bronson RT, Collin GB, Nordstrom AD, Maffei P, Paisey RB, Carey C, Macdermott S, Russell-Eggitt I, Shea SE, Davis J, Beck S, Shatirishvili G, Mihai CM, Hoeltzenbein M, Pozzan GB, Hopkinson I, Sicolo N, Naggert JK, Nishina PM: New Alström syndrome phenotypes based on the evaluation of 182 cases. Arch Intern Med 2005, 165:675-683.

29. Mokashi A, Cummings EA: Presentation and course of diabetes in children and adolescents with Alstrom syndrome. Pediatr Diabetes 2011, 12(3 Pt 2):270-275.

30. Bettini V, Maffei P, Pagano C, Romano S, Milan G, Favaretto F, Marshall JD, Paisey R, Scolari F, Greggio NA, Tosetto I, Naggert JK, Sicolo N, Vettor R: The progression from obesity to type 2 diabetes in Alström syndrome. Pediatr Diabetes 2011, doi: 10.1111/j.1399-5448.2011.00789.x.

31. Girard D, Petrovsky N: Alström syndrome: insights into the pathogenesis of metabolic disorders. Nat Rev Endocrinol 2011, 7:77-88.

32. Filler $G$, Amendt $P$, von Bredow MA, Rohde W, Ehrich JH: Slowly deteriorating insulin secretion and C-peptide production characterizes diabetes mellitus in infantile cystinosis. Eur J Pediatr 1998, 157:738-742.

33. Gahl WA, Balog JZ, Kleta R: Nephropathic cystinosis in adults: natural history and effects of oral cysteamine therapy. Ann Intern Med 2007, 147:242-250.

34. Besouw M, Levtchenko E: Growth retardation in children with cystinosis. Minerva Pediatr 2010, 62:307-314.

35. Sansanwal P, Li L, Hsieh SC, Sarwal MM: Insights into novel cellular injury mechanisms by gene expression profiling in nephropathic cystinosis. J Inherit Metab Dis 2010, 33:775-786.

36. Borgna-Pignatti C, Azzalli M, Pedretti S: Thiamine-responsive megaloblastic anemia syndrome: long-term follow-up. J Pediatr 2009, 155:295-297.

37. Bouyahia 0, Ouderni M, Ben Mansour F, Matoussi N, Khaldi F: Diabetic ketoacidosis revealing thimine responsive megaloblastic anemia. Ann Endocrinol (Paris) 2009, 70:477-479.

38. Alzahrani AS, Baitei E, Zou M, Shi Y: Thiamine transporter mutation: an example of monogenic diabetes mellitus. Eur J Endocrinol 2006, 155:787-792

39. Erdem E, Cayonu N, Uysalol E, Yildirmak ZY: Chronic intermittent form of isovaleric acidemia mimicking diabetic ketoacidosis. J Pediatr Endocrinol Metab 2010, 23:503-505.

40. Marquard J, El Scheich T, Klee D, Schmitt M, Meissner T, Mayatepek E, Oh J: Chronic pancreatitis in branched-chain organic acidurias-a case of methylmalonic aciduria and an overview of the literature. Eur J Pediatr 2011, 170:241-245.

41. Kleefstra T, Wortmann SB, Rodenburg RJ, Bongers EM, Hadzsiev K, Noordam C, van den Heuvel LP, Nillesen WM, Hollody K, GillessenKaesbach G, Lammens M, Smeitink JA, van der Burgt I, Morava E: Mitochondrial dysfunction and organic aciduria in five patients carrying mutations in the Ras-MAPK pathway. Eur J Hum Genet 2011, 19:138-144.

42. Krassas GE, Poppe K, Glinoer D: Thyroid function and human reproductive health. Endocr Rev 2010, 31:702-755.

43. Glinoer D, Delange F: The potential repercussions of maternal, fetal, and neonatal hypothyroxinemia on the progeny. Thyroid 2000, 10:871-887.

44. Farahani $H$, Ghasemi A, Roghani M, Zahediasl S: The effect of maternal hypothyroidism on the carbohydrate metabolism and insulin secretion of isolated islets in adult male offspring of rats. Horm Metab Res 2010, 42:792-797.

45. Harvey JN, Barnett D: Endocrine dysfunction in Kearns-Sayre syndrome. Clin Endocrinol (Oxt) 1992, 37:97-103.

46. Ohno K, Yamamoto M, Engel AG, Harper CM, Roberts LR, Tan GH, Fatourechi V: MELAS- and Kearns-Sayre-type co-mutation with myopathy and autoimmune polyendocrinopathy. Ann Neurol 1996, 39:761-766.

47. Hsieh RH, Li JY, Pang CY, Wei YH: A novel mutation in the mitochondrial 16S rRNA gene in a patient with MELAS syndrome, diabetes mellitus, hyperthyroidism and cardiomyopathy. J Biomed Sci 2001, 8:328-335. 
48. Pfeffer G, Sirrs S, Wade NK, Mezei MM: Multisystem disorder in late-onset chronic progressive external ophthalmoplegia. Can J Neurol Sci 2011, 38:119-123.

49. Melis D, Pivonello R, Parenti G, Della Casa R, Salerno M, Lombardi G, Sebastio G, Colao A, Andria G: Increased prevalence of thyroid autoimmunity and hypothyroidism in patients with glycogen storage disease type I. J Pediatr 2007, 15:300-305.

50. Hauser AC, Gessl A, Lorenz M, Voigtländer T, Födinger M, SunderPlassmann G: High prevalence of subclinical hypothyroidism in patients with Anderson-Fabry disease. J Inherit Metab Dis 2005, 28:715-722.

51. Faggiano A, Pisani A, Milone F, Gaccione M, Filippella M, Santoro A, Vallone G, Tortora F, Sabbatini M, Spinelli L, Lombardi G, Cianciaruso B, Colao A: Endocrine dysfunction in patients with Fabry disease. J Clin Endocrinol Metab 2006, 91:4319-4325.

52. Faggiano A, Severino R, Ramundo V, Russo R, Vuolo L, Del Prete M, Marciello F, Lombardi G, Cianciaruso B, Colao A, Pisani A: Thyroid function in Fabry disease before and after enzyme replacement therapy. Minerva Endocrinol 2011, 36:1-5.

53. Harambat J, Fargue S, Acquaviva C, Gagnadoux MF, Janssen F, Liutkus A, Mourani C, Macher MA, Abramowicz D, Legendre C, Durrbach A, Tsimaratos M, Nivet H, Girardin E, Schott AM, Rolland MO, Cochat P: Genotype-phenotype correlation in primary hyperoxaluria type 1: the pGly170Arg AGXT mutation is associated with a better outcome. Kidney Int 2010, 77:443-449.

54. Frishberg $Y$, Feinstein S, Rinat C, Drukker A: Hypothyroidism in primary hyperoxaluria type 1. J Pediatr 2000, 136:255-257.

55. Tintillier M, Pochet JM, Cosyns JP, Delgrange E, Donckier J: Late-onset primary hyperoxaluria triggered by hypothyroidism and presenting as rapidly progressive renal failure-description of a new mutation. Clin Nephrol 2004, 62:155-157.

56. Liang WC, Nishino I: State of the art in muscle lipid diseases. Acta Myol 2010, 29:351-6.

57. Benelli E, Fiore E, Giustarini E, Romani R, Pennisi E, Pinchera A, Giani C: Clear cells detection in nodular thyroid disease is not always indicative of neoplasia: description of the first case of thyroid involvement in multisystem triglyceride storage disease. Thyroid 2008, 18:1001-1003.

58. Frints SG, Lenzner $S$, Bauters $M$, Jensen $L R$, Van Esch $H$, des Portes $V$, Moog U, Macville MV, van Roozendaal K, Schrander-Stumpel CT, Tzschach A, Marynen P, Fryns JP, Hamel B, van Bokhoven H, Chelly J, Beldjord C, Turner G, Gecz J, Moraine C, Raynaud M, Ropers HH, Froyen G, Kuss AW: MCT8 mutation analysis and identification of the first female with Allan-Herndon-Dudley syndrome due to loss of MCT8 expression. Eur J Hum Genet 2008, 16:1029-37.

59. Wirth EK, Sheu SY, Chiu-Ugalde J, Sapin R, Klein M, Mossbrugger I, Quintanilla-Martinez L, Hrabé de Angelis M, Krude H, Riebel T, Rothe K, Köhrle J, Schmid KW, Schweizer U, Grüters A: Monocarboxylate transporter 8 deficiency: altered thyroid morphology and persistent high T3/T4 ratio after thyroidectomy. Eur J Endocrinol 2011, 165:555-61.

60. Ramos HE, Morandini M, Carré A, Tron E, Floch C, Mandelbrot L, Neri N, De Sarcus B, Simon A, Bonnefont JP, Amiel J, Desguerre I, Valayannopoulos V, Castanet M, Polak M: Pregnancy in women heterozygous for MCT8 mutations: risk of maternal hypothyroxinemia and fetal care. Eur J Endocrinol 2011, 164:309-314

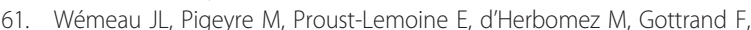
Jansen J, Visser TJ, Ladsous M: Beneficial effects of propylthiouracil plus Lthyroxine treatment in a patient with a mutation in MCT8. J Clin Endocrinol Metab 2008, 93:2084-2088.

62. Miller BS, Freeze HH: New disorders in carbohydrate metabolism: congenital disorders of glycosylation and their impact on the endocrine system. Rev Endocr Metab Disord 2003, 4:103-113.

63. Schoenmakers E, Agostine M, Mitchell C, Schoenmakers N, Papp L, Rajanayagam O, Padidela R, Ceron-Gutierrez L, Doffinger R, Prevosto C, Luan J, Montano S, Lu J, Castanet M, Clemons N, Groeneveld M, Castets P, Karbaschi M, Aitken S, Dixon A, Williams J, Campi I, Blount M, Burton H, Muntoni F, O'Donovan D, Dean A, Warren A, Brierley C, Baguley D, Guicheney P, Fitzgerald R, Coles A, Gaston H, Todd P, Holmgren A, Khanna KK, Cooke M, Semple R, Halsall D, Wareham N, Schwabe J, Grasso L, Beck-Peccoz P, Ogunko A, Dattani M, Gurnell M, Chatterjee K: Mutations in the selenocysteine insertion sequence-binding protein 2 gene lead to a multisystem selenoprotein deficiency disorder in humans. J Clin Invest 2010, 120:4220-4235
64. Dumitrescu AM, Refetoff S: Inherited defects of thyroid hormone metabolism. Ann Endocrinol (Paris) 2011, 72:95-98.

65. Schomburg L, Dumitrescu AM, Liao XH, Bin-Abbas B, Hoeflich J, Köhrle J, Refetoff S: Selenium supplementation fails to correct the selenoprotein synthesis defect in subjects with SBP2 gene mutations. Thyroid 2009, 19:277-281.

66. Hudec M, Grigerova M, Walsh CH: Secondary hypothyroidism in hereditary hemochromatosis: recovery after iron depletion. Thyroid 2008, 18:255-257.

67. Barton JC, Leiendecker-Foster C, Reboussin DM, Adams PC, Acton RT, Eckfeldt JH: Hemochromatosis and Iron Overload Screening Study Research Investigators Thyroid-stimulating hormone and free thyroxine levels in persons with HFE C282Y homozygosity, a common hemochromatosis genotype: the HEIRS study. Thyroid 2008, 18:831-838.

68. McDermott $\mathrm{JH}$, Walsh $\mathrm{CH}$ : Hypogonadism in hereditary hemochromatosis. J Clin Endocrinol Metab 2005, 90:2451-2455.

69. Valenti L, Varenna M, Fracanzani AL, Rossi V, Fargion S, Sinigaglia L: Association between iron overload and osteoporosis in patients with hereditary hemochromatosis. Osteoporos Int 2009, 20:549-555.

70. Koyama C, Hayashi H, Wakusawa S, Ueno T, Yano M, Katano Y, Goto H, Kidokoro R: Three patients with middle-age-onset hemochromatosis caused by novel mutations in the hemojuvelin gene. J Hepatol 2005, 43:740-742.

71. Buretić-Tomljanović A, Vlastelić I, Radojcić Badovinac A, StarcevićCizmarević N, Nadalin S, Ristić S: The impact of hemochromatosis mutations and transferrin genotype on gonadotropin serum levels in infertile men. Fertil Steril 2009, 91:1793-1800.

72. Giannitrapani L, Soresi M, La Spada E, Cervello M, D'Alessandro N, Montalto G: Sex hormones and risk of liver tumor. Ann N Y Acad Sci 2006, 1089:228-236

73. Waisbren SE, Potter NL, Gordon CM, Green RC, Greenstein P, Gubbels CS, Rubio-Gozalbo E, Schomer D, Welt C, Anastasoaie V, D'Anna K, Gentile J, Guo CY, Hecht L, Jackson R, Jansma BM, Li Y, Lip V, Miller DT, Murray M, Power L, Quinn N, Rohr F, Shen Y, Skinder-Meredith A, Timmers I, Tunick R, Wessel A, Wu BL, Levy H, Elsas L, Berry GT: The adult galactosemic phenotype. J Inherit Metab Dis 2011.

74. Rubio-Gozalbo ME, Gubbels CS, Bakker JA, Menheere PP, Wodzig WK, Land JA: Gonadal function in male and female patients with classic galactosemia. Hum Reprod Update 2010, 16:177-188.

75. Gubbels CS, Land JA, Rubio-Gozalbo ME: Fertility and impact of pregnancies on the mother and child in classic galactosemia. Obstet Gynecol Surv 2008, 63:334-343.

76. Forges T, Monnier-Barbarino P, Leheup B, Jouvet P: Pathophysiology of impaired ovarian failure in galactosemia. Hum Reprod Update 2006, 12:573-584.

77. Gubbels CS, Thomas CM, Wodzig WK, Olthaar AJ, Jaeken J, Sweep FC, Rubio-Gozalbo ME: FSH isoform pattern in classic galactosemia. J Inherit Metab Dis 2011, 34:387-390.

78. Rubio-Gozalbo ME, Panis B, Zimmermann LJ, Spaapen LJ, Menheere PP: The endocrine system in treated patients with classical galactosemia. $\mathrm{Mol}$ Genet Metab 2006, 89:316-322.

79. Schweitzer-Krantz S: Early diagnosis of inherited metabolic disorders towards improving outcome: the controversial issue of galactosaemia. Eur J Pediatr 2003, 162(Suppl 1):S50-S53.

80. Wang Y, Busin R, Reeves C, Bezman L, Raymond G, Toomer CJ, Watkins PA, Snowden A, Moser A, Naidu S, Bibat G, Hewson S, Tam K, Clarke JT, Charnas L, Stetten G, Karczeski B, Cutting G, Steinberg S: X-linked adrenoleukodystrophy: $A B C D 1$ de novo mutations and mosaicism. $\mathrm{Mol}$ Genet Metab 2011, 104:160-6.

81. Polgreen LE, Chahla S, Miller W, Rothman S, Tolar J, Kivisto T, Nascene D, Orchard PJ, Petryk A: Early diagnosis of cerebral X-linked adrenoleukodystrophy in boys with Addison's disease improves survival and neurological outcomes. Eur J Pediatr 2011, 170:1049-1054.

82. Assies J, Gooren LJ, Van Geel B, Barth PG: Signs of testicular insufficiency in adrenomyeloneuropathy and neurologically asymptomatic X-linked adrenoleukodystrophy: a retrospective study. Int J Androl 1997, 20:315-321.

83. Aversa A, Palleschi S, Cruccu G, Silvestroni L, Isidori A, Fabbri A: Rapid decline of fertility in a case of adrenoleukodystrophy. Hum Reprod 1998 13:2474-2479. 
84. López-Erauskin J, Fourcade S, Galino J, Ruiz M, Schlüter A, Naudi A, Jove M, Portero-Otin M, Pamplona R, Ferrer I, Pujol A: Antioxidants halt axonal degeneration in a mouse model of X-adrenoleukodystrophy. Ann Neurol 2011, 70:84-92.

85. Ebberink MS, Mooijer PA, Gootjes J, Koster J, Wanders RJ, Waterham HR: Genetic classification and mutational spectrum of more than 600 patients with a Zellweger syndrome spectrum disorder. Hum Mutat 2011, 32:59-69.

86. Sevin C, Ferdinandusse S, Waterham HR, Wanders RJ, Aubourg P: Autosomal recessive cerebellar ataxia caused by mutations in the PEX2 gene. Orphanet J Rare Dis 2011, 6:8.

87. Pierce SB, Walsh T, Chisholm KM, Lee MK, Thornton AM, Fiumara A, Opitz JM, Levy-Lahad E, Klevit RE, King MC: Mutations in the DBPdeficiency protein HSD17B54 cause ovarian dysgenesis, hearing loss, and ataxia of Perrault syndrome. Am J Hum Genet 2010, 87:282-288.

88. Pierce SB, Chisholm KM, Lynch ED, Lee MK, Walsh T, Opitz JM, Li W, Klevit RE, King MC: Mutations in mitochondrial histidyl tRNA synthetase HARS2 cause ovarian dysgenesis and sensorineural hearing loss of Perrault syndrome. Proc Natl Acad Sci USA 2011, 108:6543-6548.

89. Jaeken J: Congenital disorders of glycosylation (CDG): it's (nearly) all in it! J Inherit Metab Dis 2011, 34:853-858.

90. Vega Al, Pérez-Cerdá C, Abia D, Gámez A, Briones P, Artuch R, Desviat LR, Ugarte M, Pérez B: Expression analysis revealing destabilizing mutations in phosphomannomutase 2 deficiency (PMM2-CDG): Expression analysis of PMM2-CDG mutations. J Inherit Metab Dis 2011, 34:929-939.

91. Achouitar S, Mohamed M, Gardeitchik T, Wortmann SB, Sykut-Cegielska J, Ensenauer R, de Baulny HO, Ounap K, Martinelli D, de Vries M, McFarland R, Kouwenberg D, Theodore M, Wijburg F, Grünewald S, Jaeken J, Wevers RA, Nijtmans L, Elson J, Morava E: Nijmegen paediatric CDG rating scale: a novel tool to assess disease progression. J Inherit Metab Dis 2011, 4:923-927.

92. Lecca MR, Maag C, Berger EG, Hennet T: Fibrotic response in fibroblasts from congenital disorders of glycosylation. J Cell Mol Med 2011, 15:1788-1796

93. De Zegher F, Jaeken J: Endocrinology of the carbohydrate-deficient glycoprotein syndrome type 1 from birth through adolescence. Pediatr Res 1995, 37(4 Pt 1):395-401.

94. Kristiansson B, Stibler H, Wide L: Gonadal function and glycoprotein hormones in the carbohydrate-deficient glycoprotein (CDG) syndrome. Acta Paediatr 1995, 84:655-659.

95. Krasnewich D, O'Brien K, Sparks S: Clinical features in adults with congenital disorders of glycosylation type la (CDG-la). Am J Med Genet C Semin Med Genet 2007, 145C:302-306.

96. Coman D, McGill J, MacDonald R, Morris D, Klingberg S, Jaeken J, Appleton D: Congenital disorder of glycosylation type 1a: three siblings with a mild neurological phenotype. J Clin Neurosc 2007, 14:668-672.

97. Schoffer KL, O'Sullivan JD, McGill J: Congenital disorder of glycosylation type la presenting as early-onset cerebellar ataxia in an adult. Mov Disord 2006, 21:869-872.

98. Miller BS, Freeze HH, Hoffmann GF, Sarafoglou K: Pubertal development in ALG6 deficiency (congenital disorder of glycosylation type Ic). Mol Genet Metab 2011, 103:101-103.

99. Dahl R, Bravo Y, Sharma V, Ichikawa M, Dhanya RP, Hedrick M, Brown B, Rascon J, Vicchiarelli M, Mangravita-Novo A, Yang L, Stonich D, Su Y, Smith LH, Sergienko E, Freeze HH, Cosford ND: Potent, selective, and orally available benzoisothiazolone phosphomannose isomerase inhibitors as probes for congenital disorder of glycosylation la. J Med Chem 2011, 54:3661-3668

100. Winkler L, Offner G, Krull F, Brodehl J: Growth and pubertal development in nephropathic cystinosis. Eur J Pediatr 1993, 152:244-249.

101. Lacombe D, Germain DP, Papaxanthos-Roche A: Azoospermia as a new feature of Fabry disease. Rev Med Interne 2010, 31(Suppl 2):S214-6.

102. Gironi M, Lamperti C, Nemni R, Moggio M, Comi G, Guerini FR, Ferrante P, Canal N, Naini A, Bresolin N, DiMauro S: Late-onset cerebellar ataxia with hypogonadism and muscle coenzyme Q10 deficiency. Neurology 2004, 62:818-820.

103. Quade A, Zierz S, Klingmuller D: Endocrine abnormalities in mitochondrial myopathy with external ophthalmoplegia. Clin Invest 1992, 70:396-402.

104. Mosewich RK, Donat JR, DiMauro S, Ciafaloni E, Shanske S, Erasmus M, George D: The syndrome of mitochondrial encephalomyopathy, lactic acidosis, and strokelike episodes presenting without stroke. Arch Neurol 1993, 90:275-278.

105. Carod-Artal FJ, Herrero MD, Lara MC, López-Gallardo E, Ruiz-Pesini E, Martí R, Montoya J: Cognitive dysfunction and hypogonadotrophic hypogonadism in a Brazilian patient with mitochondrial neurogastrointestinal encephalomyopathy and a novel ECGF1 mutation. Eur J Neurol 2007, 14:581-585.

106. Ferraris S, Clark S, Garelli E, Davidzon G, Moore SA, Kardon RH, Bienstock RJ, Longley MJ, Mancuso M, Gutiérrez Ríos P, Hirano M, Copeland WC, DiMauro S: Progressive external ophthalmoplegia and vision and hearing loss in a patient with mutations in POLG2 and OPA1. Arch Neurol 2008, 65:125-131.

107. Yamasaki $R$, Ohyagi $Y$, Kawajiri M, Shigeto $H$, Ikezoe $K$, Furuya $H$, Kira J: A patient with mitochondrial encephalomyopathy presenting gynecomastia with elevation of serum estriol level. Rinsho Shinkeigaku 2004, 44:291-295.

108. Rangwala SM, Wang X, Calvo JA, Lindsley L, Zhang Y, Deyneko G, Beaulieu V, Gao J, Turner G, Markovits J: Estrogen-related receptor gamma is a key regulator of muscle mitochondrial activity and oxidative capacity. J Biol Chem 2010, 285:22619-22629.

109. Lee PJ, Patel A, Hindmarsh PC, Mowat AP, Leonard JV: The prevalence of polycystic ovaries in the hepatic glycogen storage diseases: its association with hyperinsulinism. Clin Endocrinol (Oxf) 1995, 42:601-606.

110. Strisciuglio P, Di Maio S, Parenti G, Franzese A, Lubrano P, Mariano A, Andria G: Evidence of polyglandular involvement in Niemann-Pick disease type B. Eur J Pediatr 1987, 146:431-433.

111. Bruno C, Minetti C, Tang Y, Magalhães PJ, Santorelli FM, Shanske S, Bado M, Cordone G, Gatti R, DiMauro S: Primary adrenal insufficiency in a child with a mitochondrial DNA deletion. J Inherit Metab Dis 1998, 21:155-161.

112. Nicolino M, Ferlin T, Forest M, Godinot C, Carrier H, David M, Chatelain P, Mousson B: Identification of a large-scale mitochondrial deoxyribonucleic acid deletion in endocrinopathies and deafness: report of two unrelated cases with diabetes mellitus and adrenal insufficiency, respectively. J Clin Endocrinol Metab 1997, 82:3063-3067.

113. Moraes CT, DiMauro S, Zeviani M, Lombes A, Shanske S, Miranda AF, Nakase H, Bonilla E, Werneck LC, Servidei S, et al: Mitochondrial DNA deletions in progressive external ophthalmoplegia and Kearns-Sayre syndrome. N Engl J Med 1989, 320:1293-1299.

114. Boles RG, Roe T, Senadheera D, Mahnovski V, Wong LJ: Mitochondrial DNA deletion with Kearns Sayre syndrome in a child with Addison disease. Eur J Pediatr 1998, 157:643-647.

115. Hopkins SE, Somoza A, Gilbert DL: Rare autosomal dominant POLG1 mutation in a family with metabolic strokes, posterior column spinal degeneration, and multi-endocrine disease. J Child Neurol 2010, 25:752-756.

116. Shimizu J, Inatsu A, Oshima S, Shimizu E, Hirata H, Yasuda H, Kubota T: Hyperkalemia in familial mitochondrial cytopathy. Clin Nephrol 2008, 70:348-353.

117. Shanti B, Silink M, Bhattacharya K, Howard NJ, Carpenter K, Fietz M, Clayton P, Christodoulou J: Hypoparathyroidism and insulin-dependent diabetes mellitus in a patient with Kearns-Sayre syndrome harbouring a mitochondrial DNA deletion. Clin Endocrinol (Oxf) 1996, 45:637-641.

118. Papadimitriou A, Hadjigeorgiou GM, Divari R, Papagalanis N, Comi G, Bresolin N: The influence of Coenzyme Q10 on total serum calcium concentration in two patients with Kearns-Sayre Syndrome and hypoparathyroidism. Neuromuscul Disord 1996, 6:49-53.

119. Tengan $\mathrm{CH}$, Kiyomoto BH, Rocha MS, Tavares VL, Gabbai AA, Moraes CT: Mitochondrial encephalomyopathy and hypoparathyroidism associated with a duplication and a deletion of mitochondrial deoxyribonucleic acid. J Clin Endocrinol Metab 1998, 83:125-129.

120. Gamberini MR, De Sanctis V, Gilli G: Hypogonadism, diabetes mellitus, hypothyroidism, hypoparathyroidism: incidence and prevalence related to iron overload and chelation therapy in patients with thalassaemia major followed from 1980 to 2007 in the Ferrara Centre. Pediatr Endocrinol Rev 2008, 6(Suppl 1):158-169.

121. Okada M, Higashi K, Enomoto S, Fujii Y, Yamane H, Tsujiuti K, Tanimoto S, Itoh H, Nishioka S, Yasui M, Tanaka T: A case of Wilson's disease associated with hypoparathyroidism and amenorrhea. Nippon Shokakibyo Gakkai Zasshi 1998, 95:445-449. 
122. Misery L, Gregoire M, Prieur F, Froissart R, Guffon N, Maitre S, Fond L, Denis L, Perrot JL, Cambazard F: Fabry's disease and hypoparathyroidism. Ann Med Interne (Paris) 2002, 153:283-285.

123. Tyni T, Rapola J, Palotie A, Pihko H: Hypoparathyroidism in a patient with long-chain 3-hydroxyacyl-coenzyme A dehydrogenase deficiency caused by the G1528C mutation. J Pediatr 1997, 131:766-768.

124. Baruteau J, Levade T, Redonnet-Vernhet I, Mesli S, Bloom MC, Broué P: Hypoketotic hypoglycemia with myolysis and hypoparathyroidism: an unusual association in medium chain acyl-CoA desydrogenase deficiency (MCADD). J Pediatr Endocrinol Metab 2009, 22:1175-1177.

125. Watanabe M, Asai C, Ishikawa K, Kiyota A, Terada T, Kono S, Miyajima H, Okumura A: Central diabetes insipidus and hypothalamic hypothyroidism associated with aceruloplasminemia. Intern Med 2010, 49:1581-1585.

126. Gama R, Smith MJ, Wright J, Marks V: Hypopituitarism in primary haemochromatosis, recovery after iron depletion. Postgrad Med J 1995, 71:297-298.

127. Lanes R, Muller A, Palacios A: Multiple endocrine abnormalities in a child with Blackfan-Diamond anemia and hemochromatosis Significant improvement of growth velocity and predicted adult height following growth hormone treatment despite liver damage. J Pediatr Endocrinol Metab 2000, 13:325-328.

128. Panis B, Gerver WJ, Rubio-Gozalbo ME: Growth in treated classical galactosemia patients. Eur J Pediatr 2007, 166:443-446.

129. Alter CA, Moshang T Jr: Growth hormone deficiency in two siblings with Alström syndrome. Am J Dis Child 1993, 147:97-99.

130. Koç E, Bayrak G, Suher M, Ensari C, Aktas D, Ensari A: Rare case of Alstrom syndrome without obesity and with short stature, diagnosed in adulthood. Nephrology (Carlton) 2006, 11:81-84.

131. Maffei $P$, Boschetti M, Marshall JD, Paisey RB, Beck S, Resmini E, Collin GB, Naggert JK, Milan G, Vettor R, Minuto F, Sicolo N, Barreca A: Characterization of the IGF system in 15 patients with Alström syndrome. Clin Endocrinol (Oxf) 2007, 66:269-275.

132. Bacchetta J, Fargue S, Boutroy S, Basmaison O, Vilayphiou N, Plotton I, Guebre-Egziabher F, Dohin B, Kohler R, Cochat P: Bone metabolism in oxalosis: a single-center study using new imaging techniques and biomarkers. Pediatr Nephrol 2010, 25:1081-1088.

doi:10.1186/1750-1172-7-11

Cite this article as: Vantyghem et al:. Endocrine manifestations related to inherited metabolic diseases in adults. Orphanet Journal of Rare Diseases 2012 7:11.

\section{Submit your next manuscript to BioMed Central and take full advantage of:}

- Convenient online submission

- Thorough peer review

- No space constraints or color figure charges

- Immediate publication on acceptance

- Inclusion in PubMed, CAS, Scopus and Google Scholar

- Research which is freely available for redistribution

Submit your manuscript at www.biomedcentral.com/submit 